\title{
Una nueva especie de ratón orejón del género Phyllotis Waterhouse, 1837 (Rodentia: Cricetidae) del norte del Perú
}

\author{
Víctor Pacheco ${ }^{1,2 *}$, Edgardo M. Rengifo ${ }^{1}$, and Dan Vivas ${ }^{2}$
}

Introduction: Leaf-eared mice, Phyllotis comprise a highly species-rich genus distributed in the Andes of South America from sea level to 5,500 m. This genus includes 15 species in three groups: andium/amicus, osilae, and darwini groups (sensu Steppan et al. 2007). We describe a new species of rodent of the genus Phyllotis from the northern Peruvian Andes, which has been mentioned in the literature as Phyllotis sp. nov. 1 or Phyllotis sp. and placed, in the context of a molecular phylogeny of Phyllotis, as member of the P. andium/ amicus group (Steppan et al. 2007). We also report the standard karyotype of this species and comment on its natural history. We further identify an area of endemism in the northwestern Andes of Peru, where the new species and other sigmodontines coincide in patterns of distribution.

Methodology: The new species was in detail compared with other species of Phyllotis, mainly those of the andium/amicus group. Four external and 20 cranial and dental measurements from adult specimens were employed in descriptive statistics. Sexual dimorphism was evaluated in Phyllotis nov. sp. and $P$. andium using the $t$ test. Then, to compare the new species with $P$. andium, all cranial and dental measurements were used in principal component analyses (PCA) of the covariance matrix of log-transformed measurements. Chromosome preparations were obtained from bone marrow, following Ford and Hamerton (1956).

Results: Phyllotis nov. sp. is distinguished from all other congeneric species by the combination of a relatively short tail and distinctive cranial morphology, including an comparatively long incisive foramen, a long palate that extends posteriorly beyond $\mathrm{M} 3$, mesopterygoid fossa without medial process, squamosal ridge relatively pronounced, ectotympanic large and easily visible from dorsal view, and capsular process inconspicuous or absent. The biplots of PCA show two clearly separated groups, one shaped by specimens of the new species and the other by P. andium; the new species is located mainly on the positive side of the first axis whereas $P$. andium on the negative side. The diploid number (2n) is 48 and the autosomal fundamental number (FN) is 72 .

Discussion and conclusions: The new species of Phyllotis is endemic to the Puna ecoregion of northern Peru. This discovery supports the hypothesis of a generalized biogeographical subdivision in the Puna of northwestern Peru where the ranges of several sigmodontine species coincide in an area limited by the Río Santa, the Río Marañón, and the Huancabamba depression. Based on the presence of numerous acrocentric chromosomes and the available molecular data we propose a restricted andium group to include $P$. andium, $P$. definitus, and the new species. We also summarize available data on natural history, habitat preferences, reproduction, and the systematic position of this species. The species may be threatened due to its restricted distribution, the relatively high anthropic activity in the region, and its absence in any protected area.

Key words: Andes, Biogeography, Muroidea, Phyllotini, Puna, Sigmodontinae, Taxonomy.

\footnotetext{
'Departamento de Mastozoología, Museo de Historia Natural de la Universidad Nacional Mayor de San Marcos. Av. Arenales 1256, Lima 14, Lima, Perú. E-mail: vpachecot@unmsm.edu.pe (VP), edgar_mrv@outlook.com (EMR)

2 Instituto de Ciencias Biológicas "Antonio Raimondi", Facultad de Ciencias Biológicas, Universidad Nacional Mayor de San Marcos. Av. Arenales 1256, Lima, Perú. Lima 14. Phone: 511-988078076. E-mail: jhoram_vl@hotmail.com (DV) "Corresponding author
} 
Se describe una nueva especie del roedor del género Phyllotis basado en morfología craneal y externa, datos morfométricos y citogenéticos y en secuencias moleculares del citocromo $b$. Este taxón fue comparado con todas las especies del género Phyllotis del norte de los Andes, especialmente con Phyllotis andium, con quien está más cercanamente relacionado basado en datos moleculares. La nueva especie es fácilmente distinguida de especies congenéricas esencialmente por la combinación de la cola relativa corta y una morfología craneal distintiva, que incluye un foramen incisivo que se extiende posteriormente hasta aproximadamente la mitad del anterocono del M1, paladar largo que se extiende posteriormente por detrás del M3 a una distancia aproximada a la mitad del largo del M3, fosa mesopterigoidea sin proceso medial, cresta temporal relativamente pronunciada, ectotimpánico grande y bien conspicuo desde una vista dorsal y proceso capsular inconspicuo o ausente. Los diagramas de los Análisis de Componentes Principales muestran dos grupos claramente separados, uno formado por especímenes de la nueva especie y la otra por especímenes de $P$. andium; la nueva especie está localizada principalmente en el lado positivo del primer eje mientras $P$. andium en el lado negativo. El número diploide (2n) es 48 y el número fundamental (FN) es 72; los autosómicos consisten de 13 pares metacéntricos y 10 pares acrocéntricos; el cromosoma $X$ es submetacéntrico y el $Y$ es un pequeño acrocéntrico. Esta especie nueva es endémica de la ecorregión Puna del norte del Perú; y su descubrimiento apoya la hipótesis de una subdivisión biogeográfica generalizada en la Puna del noroccidente del Perú. También presentamos datos sobre la historia natural, preferencias de hábitat y reproducción, y la posición sistemática de esta especie. Esta especie nueva podría estar ya amenazada si se considera que su rango de distribución es restringido, la alta actividad antrópica en la región y su ausencia en áreas protegidas.

Palabras clave: Andes, Biogeografía, Muroidea, Phyllotini, Puna, Sigmodontinae, Taxonomía.

Leaf-eared mice, Phyllotis Waterhouse (1837) comprise a highly species-rich genus distributed from northern Ecuador, throughout the Andes to the Strait of Magellan in southern Chile and Argentina (Tirira 2007; Pardiñas et al. 2009), from sea level to 5,500 $m$ (Hershkovitz 1962). This genus belongs to the tribe Phyllotini Vorontsov 1959 (SalazarBravo et al. 2013) and includes 15 valid species (Musser and Carleton 2005; Jayat et al. 2007; Steppan et al. 2007; Ferro et al. 2010). These rodents inhabit Andean highlands, deserts, grasslands, scrublands and Yungas (Pearson 1958; Hershkovitz 1962; Steppan 1998; Kramer et al.1999; Steppan et al. 2007; Ferro et al. 2010). Compared to other sigmodontine rodents, Phyllotis is fairly well known in morphology (Pearson 1958; Hershkovitz 1962; Braun 1993; Steppan 1995), cytogenetics (Pearson 1972; Pearson and Patton 1976; Walker et al. 1984), molecular systematics (Steppan 1998; Steppan et al. 2007; Ferro et al. 2010), and ecology and natural history (Pearson and Ralph 1978; Williams 1990; Arana et al. 2002; Crespin and Lima 2006; López-Cortés et al. 2007), but nevertheless, new species or range extensions continue to be reported (Pacheco et al. 2009; Ferro et al. 2010). 
Recently, Pacheco et al. (2009) recognized eight described species of Phyllotis for Peru ( $P$. amicus, $P$. andium, $P$. definitus, $P$. gerbillus, $P$. limatus, $P$. magister, $P$. osilae, and $P$. xanthopygus). The first four are distributed in northern Peru: $P$. amicus reported at lower and middle elevations on the western slope of the Andes, $P$. andium present at middle and high elevations, $P$. definitus restricted to the mountain region of Ancash department, and $P$. gerbillus restricted to the deserts of Piura and Lambayeque departments. Recent mammalian surveys in the highlands of the northern Peruvian Andes, from Cajamarca to Ancash departments, have revealed the existence of a new species of Phyllotis, unequivocally different from other species and sympatric with $P$. andium. This taxon has been mentioned in the literature as Phyllotis sp. nov. 1 (Steppan et al. 2007) or Phyllotis sp. (Pacheco et al. 2009; Ferro et al. 2010). Steppan et al. (2007), in the context of a molecular phylogeny of the genus Phyllotis recognized three clades within Phyllotis: the andium/amicus, the osilae, and the darwini groups. They also found that Phyllotis sp. nov. 1 (represented by the specimens MUSM 17247 [VPT 2318] and MUSM 17248 [VPT $2324]$ ) is a member of the andium/amicus group, and more closely related to $P$. andium, $P$. amicus, and $P$. gerbillus based on analyses of sequences of the cytochrome $b$ gene, or related to $P$. andium based on sequences of RAG 1 . At that time, the karyotype and natural history of this new taxon were unknown.

In this paper we describe this species and provide detailed taxonomic comparisons with the members of the P. andium/amicus group (sensu Steppan et al. 2007), and as well, other species that are distributed nearby and might potentially occur sympatrically with it. We report the karyotype of this species and provide comments on natural history. We further identify an area of endemism in the northwestern Andes of Peru, where the Material new species and other sigmodontines coincide in patterns of distribution.

\section{and Methods}

The specimens were captured with snap traps (Museum Special mousetraps) and Sherman live traps baited with a mixture of oats, peanut butter, raisins, honey and seeds (Pacheco et al. 2007). They were measured following the protocols established in Pacheco et al. (2007) and prepared either as skin and skeleton, or fixed in 10 percent formalin solution and preserved in ethanol 70 percent. Specimens were deposited at Departamento de Mastozoología, Museo de Historia Natural, Universidad Nacional Mayor de San Marcos (MUSM). Terminology of external, cranial, and postcranial morphology follows Hershkovitz (1962), Carleton (1980), Voss (1988), Carleton and Musser (1989), Voss (1993), Voss and Carleton (1993), Steppan (1995), Abdala and Diaz (2000), and Pacheco (2003). Description of fur coloration follows Smithe (1975). For the nomenclature of tooth morphology, we follow Reig (1980) and Hershkovitz (1994), but see also Carleton and Musser (1989). Descriptions of right upper and right lower molar rows were used.

Four external measurements (in $\mathrm{mm}$ ): TL, total length; $\mathrm{T}$, length of tail; $\mathrm{F}$, length of hind foot (nail included); $E$, length of ear; and W, weight (in grams) were recorded from the specimen labels. Twenty cranial and dental measurements were taken with digital calipers to the nearest $0.01 \mathrm{~mm}$ following the definitions of Myers et al. (1990): CIL, Condylo-incisive length; ZB, Zygomatic breadth; BB, Braincase breadth; IOC, Interorbital constriction; RL, Rostral length; NL, Nasal length; RW, Rostral width; RW2, Mid-rostra1 width; OL, Orbital length; DL, Diastema length; MTRL, Maxillary toothrow length; 
IFL, Incisive foramen length; AW, Alveolar width; OCW, Occipital condyle width; MB, Mastoid breadth; BOL, Basioccipital length; MFL, Mesopterygoid fossa length; MFW, Mesopterygoid fossa width; ZP, Zygomatic plate depth; and CD, Cranial depth. All analyses were restricted to specimens in age-classes III, IV and V, considered adults, following Voss (1991).

Sexual dimorphism was evaluated in Phyllotis nov. sp. and $P$. andium using the $t$ test. Then, to compare the new species with $P$. andium, all cranial and dental measurements from adult specimens were used in principal component analyses (PCA) of the covariance matrix of log-transformed measurements.

Specimens examined. We examined 126 specimens of the genus Phyllotis (Appendix 1) belonging to the following museum collections: Museo de Historia Natural, Universidad Nacional Mayor de San Marcos, Lima Perú (MUSM). Museum of Vertebrate Zoology, University of California- Berkeley, California, USA (MVZ).

Three males (MUSM 24767, 24758, 24762) and two females (MUSM 24773, 24763) of Phyllotis nov. sp. from La Libertad and Ancash Departments were karyotyped. Chromosome preparations were obtained from bone marrow, following Ford and Hamerton (1956) with modifications for rodents. Metaphases were stained with the Giemsa standard method. We determined the chromosome morphology and autosomal fundamental numbers (FN) following the nomenclature criteria used by Levan et al. (1964) and Patton (1967) respectively.

\section{Phyllotis pearsoni, new species}

Pearson's Leaf-eared Mouse

Phyllotis sp. nov. 1: Steppan et al. 2007:799.

Phyllotis sp.: Pacheco et al. 2009:10.

Holotype (Fig. 1). The holotype is an adult female specimen deposited at the Departamento de Mastozoología, Museo de Historia Natural, Universidad Nacional Mayor de San Marcos (MUSM 17431), collected by Víctor Pacheco (original field number VPT 2397) on 01 May 2003, and prepared as skin and skull, with carcass preserved in ethanol.

TyPe LoCality (Fig. 2). Campamento Callacuyán, Laguna Negra, 4,028 m, Quiruvilca District, Santiago de Chuco Province, La Libertad Department, Peru, at approximately $-7^{\circ} 57^{\prime} 4.5 \mathrm{~S},-78^{\circ} 14^{\prime} 14.6 \mathrm{~W}$.

Paratype. Paratypes include seven adult specimens (MUSM 17429, 17430, 17432, 17436--17439). Selected measurements of the holotype and paratype specimens are provided in Table 1.

Etymology. Phyllotis pearsoni is named in honor of Oliver P. Pearson, the first mammalogist to carry out an exhaustive review of the genus Phyllotis in 1958 with his work "A taxonomic revision of the rodent genus Phyllotis", which provided the principal base for future studies; for his generosity to the senior author who received his first Sherman traps from him, and for supporting him during a visit to the MVZ collection; and last but not least for being an inspiration to the authors and numerous students of mammals. 
Figure 1. Dorsal, ventral and lateral views of cranium and mandible of Phyllotis pearsoni nov. sp. (MUSM 17431, holotype). Scale is $10 \mathrm{~mm}$.

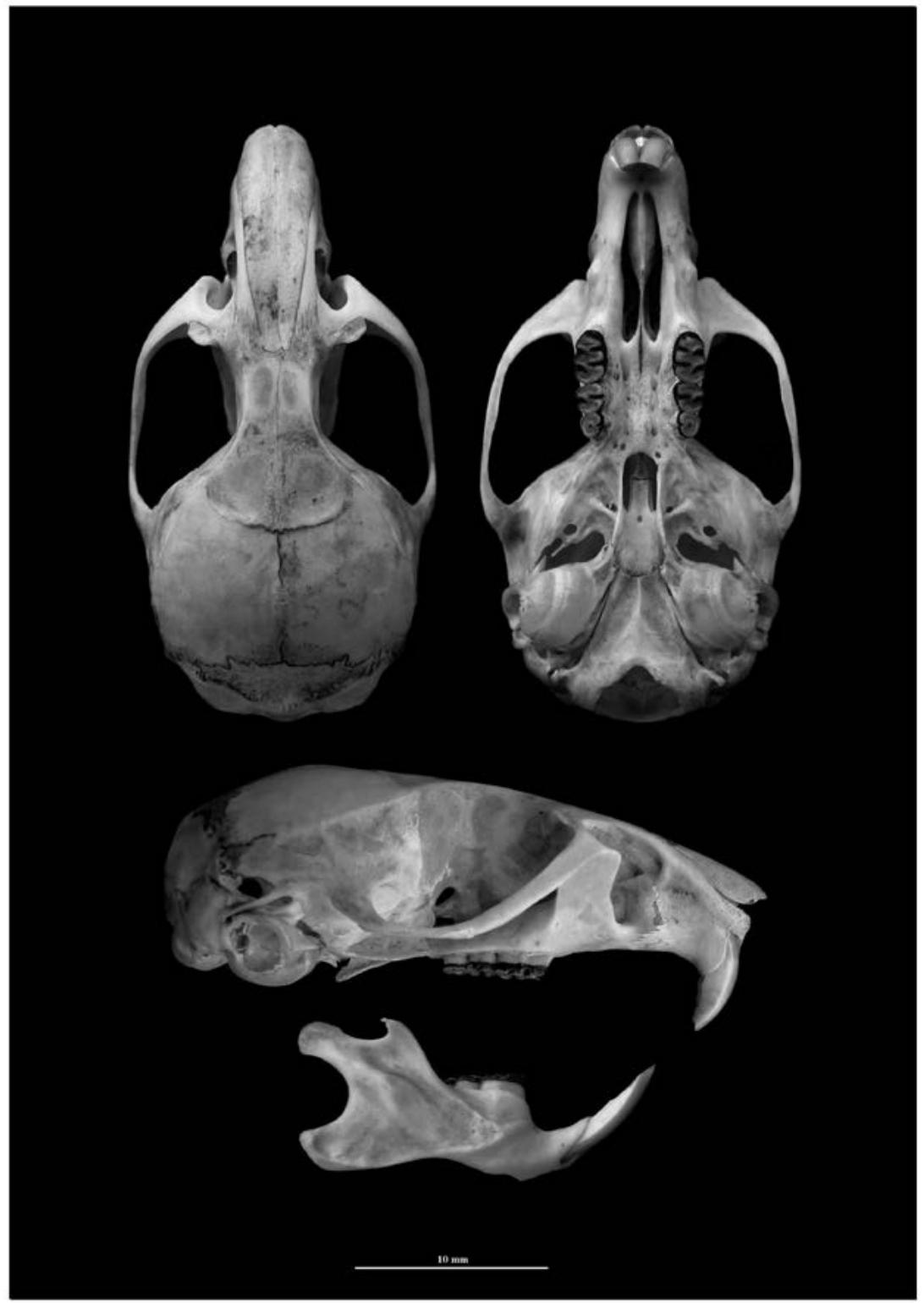

Distribution. Phyllotis pearsoni occurs in the Puna of northern Peru, from the District of Huasmín, south of Department Cajamarca, to the District of Pallasca, north of Department Ancash (Fig. 2). The elevational range is from 3572 to $4270 \mathrm{~m}$.

Diagnosis (Figs. 1, 3). The new species is a medium-size Leaf-eared Mouse $(T L=203$ to $249 \mathrm{~mm}$ ) that can be distinguished from other species of Phyllotis by the following combination of characters: tail relatively short (41 to $49 \%$ of total length); anterior margin of nasals broad and spatulate, extending slightly beyond the face of the upper incisors; posteriorly, each nasal tapers to a narrow point posterior to the premaxillae and the maxilla-frontal-lacrimal joint; zygomatic plate vertical and moderately broad with the anterior margin concave; interorbital region narrow with parallel sides and sharp edges; incisive foramina long, extending posteriorly between M1 to about half the anterocone; palate long, extending posteriorly beyond M3 by a distance of about half the length of M3 or little longer; mesopterygoid fossa U-shaped, without a medial process; squamosal 
ridge comparatively pronounced; ectotympanic bone large and well visible from dorsal view; M1 procingulum undivided and half-moon shaped; $\mathrm{m} 1$ procingulum with an anteromedian flexid; and capsular process of the lower incisors indistinct or absent.

Description (Figs. 1, 3). Phyllotis pearsoni exhibit long fur, $17.0 \mathrm{~mm}$ in average; guard hairs reach $23.0 \mathrm{~mm}$ and the pelage is soft with silky texture. The dorsum is grayish brown, the sides are somewhat more yellowish, both moderately contrasting with the venter. The hairs of dorsal pelage are slate color at the base (color 83 dark neutral grey)

\begin{tabular}{|c|c|c|c|c|c|c|c|c|}
\hline & $\begin{array}{l}\text { Holotype } \\
17431 \\
(\text { III, f) }\end{array}$ & $\begin{array}{l}\text { Paratype } \\
17429 \\
(\mathrm{II}, \mathrm{m})\end{array}$ & $\begin{array}{l}\text { Paratype } \\
17430 \\
(\text { III, m) }\end{array}$ & $\begin{array}{l}\text { Paratype } \\
17432 \\
(\mathrm{II}, \mathrm{f})\end{array}$ & $\begin{array}{l}\text { Paratype } \\
17436 \\
(\mathrm{IV}, \mathrm{m})\end{array}$ & $\begin{array}{l}\text { Paratype } \\
17437 \\
(\mathrm{III}, \mathrm{m})\end{array}$ & $\begin{array}{l}\text { Paratype } \\
17438 \\
(\mathrm{IV}, \mathrm{m})\end{array}$ & $\begin{array}{l}\text { Paratype } \\
17439 \\
(\mathrm{~V}, \mathrm{~m})\end{array}$ \\
\hline TL & 243.0 & 230.0 & - & 214.0 & 240.0 & 230.0 & 233.0 & 256.0 \\
\hline $\mathrm{T}$ & 113.0 & 108.0 & - & 101.0 & 114.0 & 110.0 & 109.0 & 122.0 \\
\hline $\mathrm{F}$ & 26.0 & 27.5 & - & 26.0 & 27.0 & 26.0 & 27.0 & 28.0 \\
\hline$E$ & 23.0 & 22.5 & - & 23.0 & 25.0 & 29.0 & 22.5 & 22.5 \\
\hline W & 59.0 & 47.0 & - & 48.0 & 55.0 & 50.0 & 55.5 & 55.0 \\
\hline CIL & 29.18 & 27.93 & 28.58 & 27.09 & 29.34 & 28.35 & 28.82 & 29.37 \\
\hline ZB & 16.36 & 16.02 & 16.07 & 15.48 & 16.43 & 16.23 & 16.58 & 16.50 \\
\hline BB & 13.84 & 13.83 & 13.75 & 13.97 & 14.31 & 14.10 & 14.12 & 14.06 \\
\hline IOC & 4.10 & 4.09 & 4.08 & 4.02 & 4.04 & 4.31 & 3.95 & 4.01 \\
\hline RL & 10.10 & 9.67 & 9.95 & 9.75 & 10.53 & 10.63 & 10.02 & 10.45 \\
\hline NL & 12.26 & 12.29 & 12.93 & 12.02 & 12.54 & 12.93 & 12.07 & 12.90 \\
\hline RW & 5.73 & 5.50 & 5.68 & 5.13 & 5.88 & 5.71 & 5.64 & 5.78 \\
\hline RW2 & 4.83 & 4.52 & 4.56 & 4.14 & 4.70 & 4.55 & 4.34 & 4.36 \\
\hline OL & 11.09 & 10.56 & 10.48 & 10.38 & 11.26 & 11.02 & 10.61 & 10.96 \\
\hline $\mathrm{DL}$ & 8.09 & 7.80 & 8.12 & 7.59 & 8.34 & 8.25 & 7.96 & 8.67 \\
\hline MTRL & 5.59 & 5.41 & 5.31 & 5.13 & 5.69 & 5.39 & 5.39 & 5.06 \\
\hline IFL & 7.52 & 7.00 & 7.17 & 6.63 & 7.65 & 7.64 & 7.45 & 7.75 \\
\hline AW & 6.21 & 6.18 & 5.82 & 5.90 & 6.08 & 5.99 & 6.10 & 6.02 \\
\hline OCW & 6.80 & 7.24 & 6.85 & 6.66 & 7.13 & 7.09 & 6.88 & 7.12 \\
\hline$M B$ & 13.17 & 13.03 & 13.07 & 13.14 & 13.33 & 13.56 & 13.33 & 13.12 \\
\hline BOL & 2.36 & 2.34 & 2.17 & 2.21 & 2.34 & 2.26 & 2.28 & 2.29 \\
\hline BFL & 4.12 & 3.95 & 3.56 & 3.23 & 3.83 & 3.80 & 4.04 & 3.73 \\
\hline MFL & 1.81 & 1.44 & 1.75 & 1.56 & 1.73 & 1.76 & 1.73 & 1.40 \\
\hline ZP & 3.37 & 3.29 & 3.21 & 2.89 & 3.11 & 3.18 & 2.95 & 3.08 \\
\hline $\mathrm{CD}$ & 11.59 & 11.48 & 11.79 & 11.02 & 11.45 & 11.46 & 11.82 & 11.42 \\
\hline
\end{tabular}

and tips brownish (color 26 clay in juvenile individuals or 39 cinnamon in old adult individuals). The hairs on ventral pelage are slate at the base (color 83 dark neutral grey) and tips whitish or white-yellowish. The hairs on the chin are dark gray-based with whitish tips. A pectoral streak is weakly visible or absent. Ears are large with a fine internal dark brown fur (38 tawny or 40 cinnamon-rufous) and a distinct antitragus. A small pale brown auricular patch behind the ears is present. Genal, superciliary, submental, interramal, and mystacial vibrissae are present; mystacial and superciliary 
vibrissae are long, but not extending posteriorly behind pinnae when laid back against head. The dorsal surface of manus is covered with fine white hairs; ungual tuft covers the claws, and the margins of the ventral surface of claws are closed at base. The digit I of manus is distinctly shorter than digit $\mathrm{V}$, and this is shorter than the digit II. The hindfeet are slender and moderately long with metatarsals and digits white, and heels furred; the claws are covered by very long ungual tufts. Six small plantar pads are present. The hypothenar is smaller than the thenar and separated from it by a gap. The plantar surface separating pads is squamated.

Digit I is very short, the claw reaches half the length of phalanx 1 of digit II. The claw of digit $\mathrm{V}$ extends to the interphalangeal joint of digit IV. The tail is comparatively short, shorter than body and head length or subequal (41 to $49 \%$ of total length), and bicolor (dark dorsally and neutral gray ventrally); dorsal and ventral sides are furred, with fur covering indistinct scales and the hairs individually extending more than 3 scale rows.

A distinct pencil tuft on the tip of the tail is absent. Four pairs of mammae are present in pectoral, thoracic, abdominal and inguinal position (sensu Pacheco 2003).

The skull of Phyllotis pearsoni is comparatively large (Fig. 1). The rostrum is robust and broad (in dorsal view) and moderately deep at level of the zygomatic plate (in lateral view). The nasals are long and spatulate, projecting anteriorly slightly beyond the

Figure 2. Map showing: A) the collecting localities of Phyllotis pearsoni nov. sp. in Peru, B) polygons of species distribution of Phyllotis present in northern Peru.
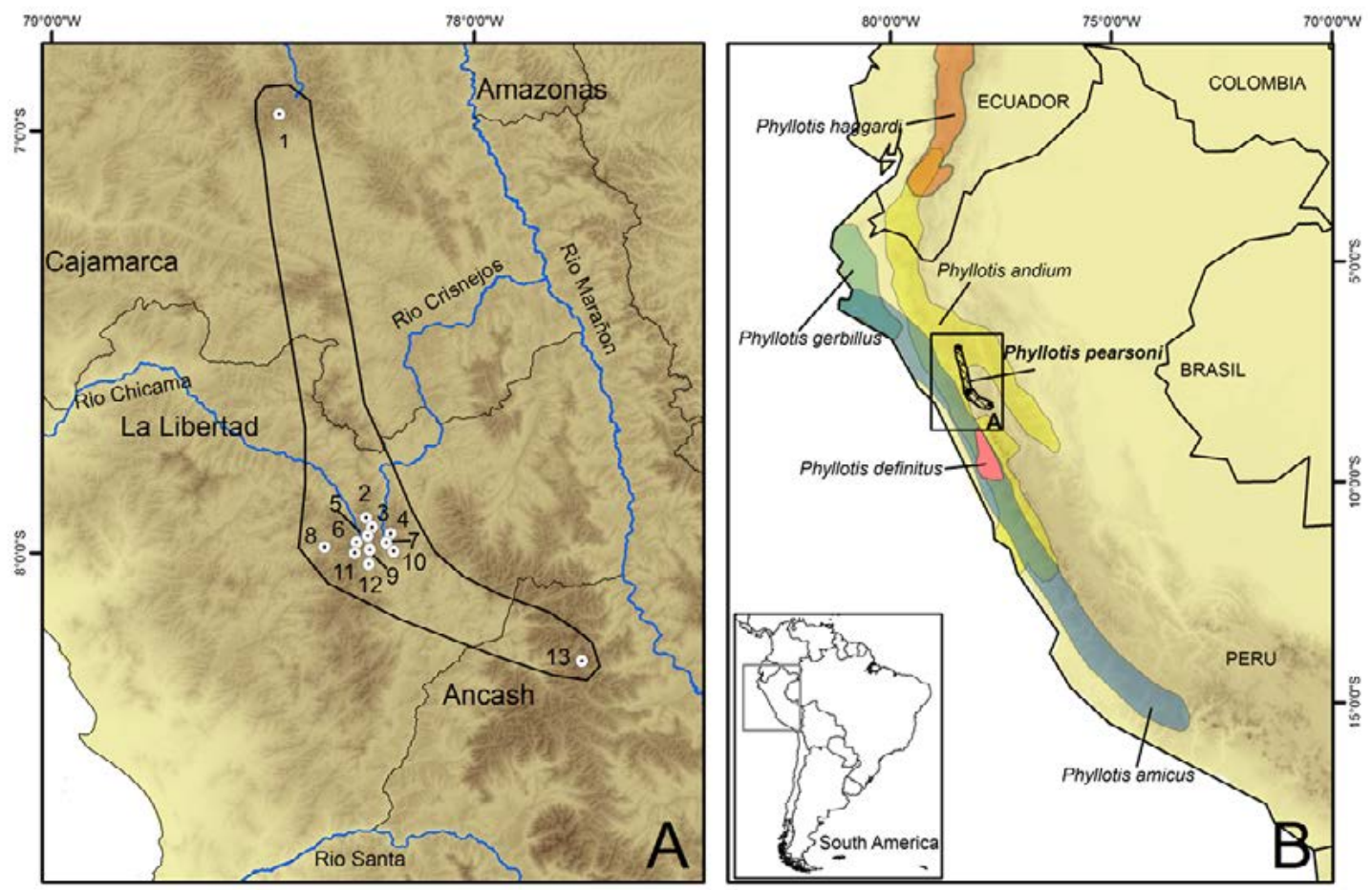

premaxillae and the anterior border of the incisors, and tapering posteriorly to a narrow point posterior to the premaxillae and the maxillary-frontal-lacrimal suture. The anterior margin of the premaxillae is short and narrow and extends beyond the incisors. The premaxillae form a pronounced ridge dorsal to the nasolacrimal foramen and just over the maxillae. The zygomatic plate is broad with the anterior margin smoothly concave, and the zygomatic notch is deep with the zygomatic spine slightly protruding. The superficial masseteric scar is small but visible and placed slightly posterior to the ventral 
root of the zygomatic plate. The infraorbital foramen is narrow, wider dorsally (in frontal view). The antorbital bridge is very high and lies just below the dorsal surface of the rostrum, and a large trapezoidal or squarish lacrimal attaches to it. The zygomatic arch in dorsal view is robust, with parallel sides that are weakly convergent anteriorly. The zygomatic process of the maxillae is narrow and barely wider than the antorbital bridge.

The jugal is long and slender. The interorbital region is narrow, with parallel and gently squared margins, with the supraorbital foramina located slightly below. The braincase is rounded, the fronto-parietal suture is slightly serrated and U-shaped; the squamosalparietal suture is smooth with a lateral parietal process. The interparietal is small and antero-posteriorly short, with margins exhibiting indented sutures. The palatal region is long (sensu Hershkovitz 1962) and slightly grooved; it extends behind the posterior plane of M3 by a distance of about half the length of M3 or a little more; and the posterolateral palatal pits are small and placed anterior to the mesopterygoid fossa and behind M3.

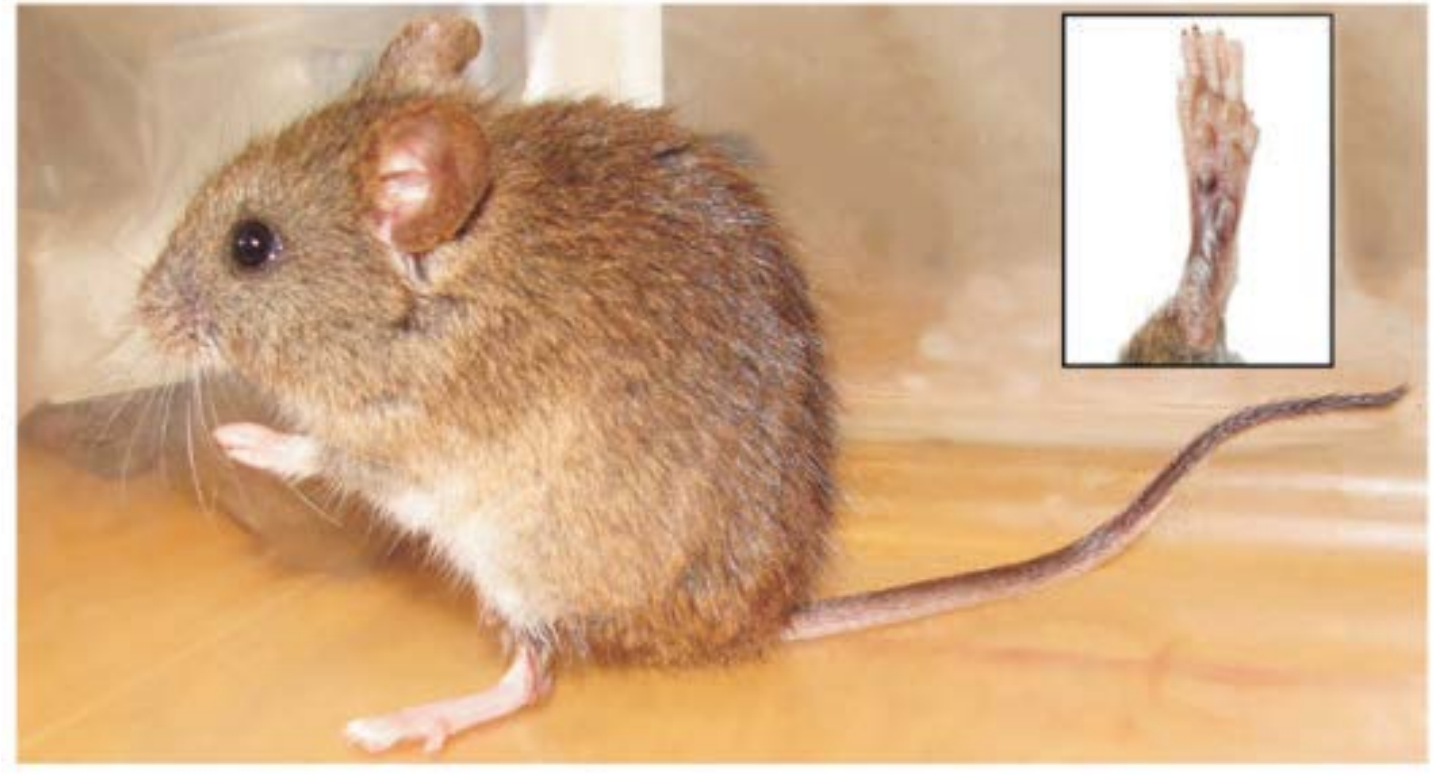

Figure 3. An external view of Phyllotis pearsoni nov. sp. (MUSM 24762); a plantar view of the hind foot is also inserted (MUSM 24765). Not at scale. Photographs by Víctor Pacheco.

The diastema (in lateral view) is mainly flat. The incisive foramina are long and narrow with parallel margins. The premaxillary portion of the septum separating right and left foramina is broad and extends half the length of the foramina, while the maxillary portion of septum is long and thin. The maxillary base of the molars is broad and sub-rectangular, and clearly visible form dorsal view (sensu Pacheco 2003). The mesopterygoid fossa is narrow and $U$-shaped. The sphenopalatine vacuities are large and wide, exposing the presphenoid. The parapterygoid fossa is triangular and wide, with inconspicuous vacuities. The posterior opening of the alisphenoid canal is large with a distinct groove for the infraorbital artery. The middle lacerate foramen is very open, extending anteriorly beyond the level of the bony Eustachian tube; the alisphenoid extends from anterior edge of tympanic bullae to the sphenopalatine foramen, and the alar fissure is shallow.

The alisphenoid strut is absent. A small anterior opening of alisphenoid canal and a long foramen oval are present. The ethmoid foramen is small and located dorsal to M2.

The ethmoturbinals are of moderate size. The optic and the orbitosphenoid foramina are large and posterior to M3. The carotid circulation corresponds to the "primitive" 
condition (sensu Voss 1988) with a large stapedial foramen, squamosal-alisphenoid groove and a conspicuous sphenofrontal foramen. The internal carotid is moderately large and bordered by the basioccipital bone, the ectotympanic portion of the auditory bullae, and the petrosal. The ectotympanic bullae are globose. The tegmen tympani overlaps the posterior suspensory process of the squamosal and a sinus groove is present.

The ectotympanic ring is closed, and the dorsal margin of the ectotympanic extends posteriorly to contact the petrosal (sensu Pacheco 2003). The ectotympanic is also large and easily visible from dorsal view. The bony Eustachian tubes are long and extend to the posterior margin of the parapterygoid fossae. The anterior process (stapedial spine) is long and slender, but does not reach the posterior margin of the alisphenoid bone.

The malleus lamina is square with a long and thin manubrium; the orbicular apophysis is large and digit-like; the processus brevis of the incus is narrow with knob-like tip.

The postglenoid foramen is smaller than the subsquamosal fenestra, and the two are separated by a long and narrow hamular process that reaches the mastoid bone. The lambdoid ridge is absent. The basioccipital is sub triangular and divided by a shallow medial ridge. The mastoid (periotic capsule of petrosal) is square with a moderately large fenestra. The occipital condyles are not conspicuous in dorsal view; the paraoccipital processes are small and located posterior to the hypoglossal foramen; and the foramen magnum is rounded. The hyoid apparatus is composed of an arched basihyal with an entoglossal process weakly developed, a short thyrohyal, and a ceratohyal with free and spatulated tip.

The upper incisors are large and deep with moderately opisthodont orientation (sensu Hershkovitz 1962), lacking incisor grooves, and with rounded or blunt tips, the wear surface facing posteriorly. The tooth topography conforms to the tetralophodont dental pattern, with slightly hypsodont crown and cusp arrangement on $\mathrm{M} 1$ and $\mathrm{m} 1$ respectively slightly alternate and alternate. The toothrows are parallel. The anterior margin of M1 is just ventral to the posterior margin of the zygomatic plate; the procingulum is undivided and rounded, with a half-moon shape; the paraflexus and metaflexus are wider than protoflexus and mesoflexus; the paracone and metacone are slightly narrower than protocone and hypocone. M2 presents as an " $\mathrm{S}$ " shape, the hypoflexus is slightly deep projecting perpendicularly to the tooth and narrower than mesoflexus. $M 3$ is $2 / 3$ or $3 / 4$ the size of $M 2$, with a shallow hypoflexus and a distinct lake left by a worn metaflexus.

The procingulum of $\mathrm{m} 1$ exhibits an anteromedian flexid and an anterior fossetid in unworn molars. In $\mathrm{m} 2$, the protoflexid is weakly developed or absent, the hypoflexid and mesoflexid are distinct, and a narrow and oblique posteroflexid is observed in unworn molars. The $\mathrm{m} 3$ is smaller than $\mathrm{m} 2$ but the hypoflexid and mesoflexid are conspicuous.

The mandible has a slightly concave or sigmoid ventral margin. The superior and inferior masseteric crests converge in front of the anterior margin of $\mathrm{m} 1$; the mental foramen is high and located on the dorsal surface of diastema; the capsular process of the lower incisor alveolus is indistinct. The coronoid process is small and level with the condylar process, and the sigmoid notch between them is shallow and horizontal; the condylar process is robust, dorsal, and posterior to the angular process with a deep angular notch

Phyllotis pearsoni has seven cervical, thirteen thoracic, six lumbar, four sacral and twenty-nine caudal vertebrae. The humerus has a large entepicondylar foramen and a 
large distinct deltoid crest; a large supratrochlear foramen is present. The calcaneum is short with a gap between the proximal edge of the trochlear process and the posterior articulation facet. The tibia and fibula are fused for more than 40 percent of the length of the tibia, and the tibia-femur ratio is 80 percent. The three middle metatarsals are longer than lateral ones (I-V). Metatarsal III is barely longer than IV and II, the metatarsal V is longer than I. The peroneal process of the fifth metatarsal does not reach the proximal edge of cuboid bone.

The morphology of the stomach conforms to the unilocular-hemiglandular pattern (Carleton 1973), in which the bordering fold crosses the lesser curvature at the apex of the incisura angularis, then recurves sharply and passes to the left of the esophageal orifice. The corpus contains some glandular epithelium, similar to the figure of Thomasomys paramorum in Carleton (1973: Fig 4a). The gall bladder is present.

Karyotype. Phyllotis pearsoni has a diploid number $(2 \mathrm{n})=48$ and an autosomal fundamental number $(\mathrm{FN})=72$. The autosomal chromosome complement consists of two groups, the first comprises 13 pairs of metacentrics and the second by 10 pairs of acrocentric chromosomes. The $\mathrm{X}$ chromosome is submetacentric and the $\mathrm{Y}$ chromosome is a small acrocentric (Fig. 4).

\section{IfHแ)

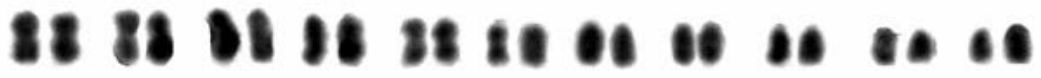

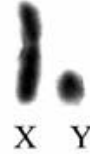 \\ Figure 4. Standard Gi e m s a - stain ed karyotype of Phyllotis pearsoni nov. sp. $(2 \mathrm{n}$ $=48, \mathrm{FN}=72$ ) from a male specimen (MUSM 24767), Río Caballo Moro, La Libertad Department. Scale bar $=5 \mu \mathrm{m}$.}

Comparisons. Steppan et al. (2007) recognized the andium/amicus, the osilae, and the darwini groups within the genus Phyllotis. Morphologically, P. pearsoni is readily separated from members of the osilae and darwini groups by the short tail (short or subequal to head and body length) versus longer tail (longer than head and body length), and by the robust rostrum. In addition, compared to the osilae group, P. pearsoni exhibit a weak pectoral streak, and the posteropalatal pits placed anterior to the mesopterygoid fossae versus a clear pectoral streak and posteropalatal pits located at both sides of the mesopterygoid fossae. $P$. pearsoni mainly requires further comparisons with the members of the andium/amicus group, to which it belongs.

Phyllotis pearsoni is similar to $P$. andium in fur coloration but is a distinctly larger mouse with proportionally shorter tail (Fig. 5, Table 2). In P. pearsoni, the guard hairs in the dorsal pelage are longer $(17 \mathrm{~mm}$ versus $10 \mathrm{~mm})$, and the hindfoot is relatively shorter. The cranium of $P$. pearsoni is larger than that of $P$. andium; the rostrum is also more robust, and the nasals are wider. Other differences in a comparison of $P$. pearsoni with $P$. andium include the following: broader zygomatic plate, deeper zygomatic notch and more distinct zygomatic spine, more robust zygomatic arch (in dorsal view), narrower interorbital region (Fig. 6A), U-shaped mesopterygoid fossa versus squarish in $P$. andium, broader presphenoid, and more open middle lacerate foramen (Fig. 6B). The features in dentition are very similar, but in $P$. pearsoni the toothrow is longer (Table 2), the M1 
procingulum is broader, and the M1 procingulum is half-moon shaped versus slightly ovoid in P. andium (Fig. 7A). The procingulum of $\mathrm{m} 1$ of $P$. pearsoni exhibits a small lingual flexid which is absent in $P$. andium (Fig. 7B). Also, an anterior fossetid in unworn $\mathrm{m} 1$ is more frequent in $P$. pearsoni. The mandible of $P$. pearsoni is larger and the capsular process of the lower incisor alveolus is inconspicuous or absent versus moderate or conspicuous in $P$. andium.

Phyllotis pearsoni is distinctly much larger compared to $P$. amicus (Table 2). Also, the ears, tail, and hindfeet of $P$. pearsoni are proportionally shorter in relation to head and body length than those of $P$. amicus, and the dorsal and ventral pelage of $P$. pearsoni is distinctly less strongly countershaded. The superciliary vibrissae in $P$. pearsoni extend only to the pinnae, while those of $P$. amicus are very long, extending posteriorly behind pinnae when laid back along the body. P. pearsoni lacks a pencil at the tip of the tail, a feature that is present in $P$. amicus. Cranially, $P$. pearsoni is much larger, the rostrum is more robust, and the toothrow is longer; the tympanic bullae, however, are proportionally smaller, and the interorbital region is narrower.

Phyllotis pearsoni is slightly smaller than Phyllotis definitus (Table 2). In P. pearsoni the dorsal pelage is grayish and the ventral pelage is whitish versus the cinnamon brown dorsal pelage and grayish ventral coloration of $P$. definitus. The tail in $P$. pearsoni is clearly more bicolor. The cranium of $P$. pearsoni is slightly smaller with a narrower rostrum, and

Table 2. Average measurements of Phyllotis pearsoni nov. sp., P. andium, P. amicus, $P$. gerbillus, $P$. definitus, and $P$. haggardi listed in Appendix 1. Weight is given in grams and measurements in millimeters (see abbreviations in the text). Mean and Standard deviation (above), observed range and sample size in parenthesis (below).

\begin{tabular}{|c|c|c|c|c|c|c|}
\hline Variable & P. pearsoni & P. andium & P. amicus & P. gerbillus & P. definitus & P. haggardi \\
\hline TL & $\begin{array}{c}228.5 \pm 12.50 \\
203.0-249.0 \\
(22)\end{array}$ & $\begin{array}{c}231.5 \pm 12.92 \\
201.0-254.5 \\
(36)\end{array}$ & $\begin{array}{c}197.2 \pm 9.29 \\
189.0-208.0(4)\end{array}$ & $\begin{array}{c}160.5 \pm 5.50 \\
155.0-165.0(3)\end{array}$ & $\begin{array}{c}244.5 \pm 16.97 \\
222.0-272.0(8)\end{array}$ & $\begin{array}{c}171.0 \pm 16.97 \\
159.0-183.0 \\
(2)\end{array}$ \\
\hline $\mathrm{T}$ & $\begin{array}{c}107.3 \pm 7.56 \\
92.0-122.0(22)\end{array}$ & $\begin{array}{c}120.7 \pm 8.36 \\
101.0-136.0 \\
(36)\end{array}$ & $\begin{array}{l}108.6 \pm 13.05 \\
94.0-119.0(3)\end{array}$ & $\begin{array}{l}79.5 \pm 4.51 \\
75.0-84.0(3)\end{array}$ & $\begin{array}{c}121.1 \pm 9.92 \\
101.0-136.0(9)\end{array}$ & $\begin{array}{l}77.00 \pm 9.90 \\
70.0-84.0(2)\end{array}$ \\
\hline $\mathrm{F}$ & $\begin{array}{c}26.4 \pm 1.56 \\
22.5-30.0(25)\end{array}$ & $\begin{array}{c}25.2 \pm 1.08 \\
23.0-27.0(39)\end{array}$ & $\begin{array}{c}22.5 \pm 0.58 \\
22.0-23.0(4)\end{array}$ & $\begin{array}{c}19.0 \pm 1.15 \\
18.0-20.0(3)\end{array}$ & $\begin{array}{c}29.4 \pm 0.88 \\
28.0-31.0(9)\end{array}$ & $\begin{array}{c}23.0 \pm 0 \\
23.0-23.0(2)\end{array}$ \\
\hline $\mathrm{E}$ & $\begin{array}{c}23.3 \pm 1.26 \\
21.00-25.5(25)\end{array}$ & $\begin{array}{c}22.1 \pm 1.31 \\
20-25(39)\end{array}$ & $\begin{array}{c}22.5 \pm 3 \\
19.0-25.0(4)\end{array}$ & $\begin{array}{c}15.5 \pm 1.53 \\
14.0-17.0(3)\end{array}$ & $\begin{array}{c}23.5 \pm 1.01 \\
22.0-25.0(9)\end{array}$ & $\begin{array}{c}22.0 \pm 0 \\
22.0-22.0(2)\end{array}$ \\
\hline W & $\begin{array}{c}51.2 \pm 6.35 \\
41.0-68.0(24)\end{array}$ & $\begin{array}{c}39.0 \pm 8.78 \\
22.5-55.0(39)\end{array}$ & $\begin{array}{l}24.5 \pm 4.43 \\
18.0-28.0(4)\end{array}$ & $\begin{array}{c}15.5 \\
15.5(1)\end{array}$ & $\begin{array}{l}63.0 \pm 12.91 \\
50.0-89.0(9)\end{array}$ & $\begin{array}{c}29.5 \pm 0.71 \\
29.0-30.0(2)\end{array}$ \\
\hline CIL & $\begin{array}{c}28.54 \pm 0.97 \\
26.28-30.29 \\
(24)\end{array}$ & $\begin{array}{c}26.18 \pm 1.16 \\
23.63-27.79 \\
(41)\end{array}$ & $\begin{array}{c}23.54 \pm 1.64 \\
21.81-25.55(4)\end{array}$ & $\begin{array}{c}20.58 \pm 0.26 \\
20.37-20.89(3)\end{array}$ & $\begin{array}{c}29.74 \pm 1.35 \\
28.31-33.02(9)\end{array}$ & $\begin{array}{c}24.09 \pm 0.38 \\
23.82-24.36 \\
\text { (2) }\end{array}$ \\
\hline ZB & $\begin{array}{c}16.22 \pm 0.57 \\
15.22-17.31 \\
(25)\end{array}$ & $\begin{array}{c}14.58 \pm 0.54 \\
13.55-15.73 \\
(41)\end{array}$ & $\begin{array}{c}13.21 \pm 1.05 \\
12.22-14.29(4)\end{array}$ & $\begin{array}{c}12.21 \pm 0.41 \\
11.77-12.59 \\
\text { (3) }\end{array}$ & $\begin{array}{c}16.66 \pm 0.58 \\
16.21-18.15(9)\end{array}$ & $\begin{array}{l}13.66 \pm 0.47 \\
13.33-14(2)\end{array}$ \\
\hline $\mathrm{BB}$ & $\begin{array}{c}13.78 \pm 0.28 \\
13.03-14.24 \\
(25)\end{array}$ & $\begin{array}{c}12.72 \pm 0.35 \\
11.86-13.34 \\
(42)\end{array}$ & $\begin{array}{c}11.99 \pm 0.56 \\
11.5-12.56(4)\end{array}$ & $\begin{array}{c}11.05 \pm 0.16 \\
10.94-11.23(3)\end{array}$ & $\begin{array}{c}14.16 \pm 0.33 \\
13.77-14.75(9)\end{array}$ & $\begin{array}{c}12.21 \pm 0.16 \\
12.1-12.32(2)\end{array}$ \\
\hline IOC & $\begin{array}{c}4.19 \pm 0.12 \\
3.85-4.37(25)\end{array}$ & $\begin{array}{c}4.25 \pm 0.20 \\
3.91-4.95(42)\end{array}$ & $\begin{array}{c}4.11 \pm 0.08 \\
3.99-4.17(4)\end{array}$ & $\begin{array}{c}3.87 \pm 0.07 \\
3.79-3.91(3)\end{array}$ & $\begin{array}{c}4.5 \pm 0.16 \\
4.24-4.79(9)\end{array}$ & $\begin{array}{l}4.32 \pm 0.02 \\
4.3-4.33(2)\end{array}$ \\
\hline RL & $\begin{array}{c}10.16 \pm 0.45 \\
9.42-11.35(25)\end{array}$ & $\begin{array}{c}9.22 \pm 0.52 \\
8.15-10.22 \\
\quad(41)\end{array}$ & $\begin{array}{c}8.14 \pm 0.22 \\
7.92-8.42(4)\end{array}$ & $\begin{array}{l}7.51 \pm 0.27 \\
7.25-7.78(3)\end{array}$ & $\begin{array}{l}10.33 \pm 0.57 \\
9.7-11.56(9)\end{array}$ & $\begin{array}{l}8.65 \pm 0.06 \\
8.61-8.7(2)\end{array}$ \\
\hline
\end{tabular}

Continuous.. 


\begin{tabular}{|c|c|c|c|c|c|c|}
\hline $\begin{array}{l}\text { Continuous.. } \\
\text { Variable }\end{array}$ & P. pearsoni & $P$. andium & P. amicus & P. gerbillus & P. definitus & P. haggardi \\
\hline NL & $\begin{array}{c}12.45 \pm 0.39 \\
11.3-13.15(25)\end{array}$ & $\begin{array}{c}11.44 \pm 0.55 \\
10.35-12.73 \\
(41)\end{array}$ & $\begin{array}{c}10.30 \pm 0.33 \\
10.00-10.62(4)\end{array}$ & $\begin{array}{l}8.91 \pm 0.10 \\
8.79-8.99(3)\end{array}$ & $\begin{array}{c}12.90 \pm 0.76 \\
12.23-14.67(9)\end{array}$ & $\begin{array}{c}11.11 \pm 0.11 \\
11.03-11.18 \\
(2)\end{array}$ \\
\hline RW & $\begin{array}{c}5.61 \pm 0.32 \\
4.9-6.25(25)\end{array}$ & $\begin{array}{c}5.13 \pm 0.33 \\
4.61-5.70(42)\end{array}$ & $\begin{array}{l}4.52 \pm 0.53 \\
3.95-5.02(4)\end{array}$ & $\begin{array}{l}3.91 \pm 0.07 \\
3.83-3.96(3)\end{array}$ & $\begin{array}{c}5.98 \pm 0.45 \\
5.50-7.00(9)\end{array}$ & $\begin{array}{c}4.74 \pm 0.06 \\
4.69-4.78(2)\end{array}$ \\
\hline RW2 & $\begin{array}{c}4.62 \pm 0.29 \\
3.88-5.19(25)\end{array}$ & $\begin{array}{c}4.30 \pm 0.21 \\
3.76-4.73(42)\end{array}$ & $\begin{array}{c}3.77 \pm 0.39 \\
3.37-4.13(4)\end{array}$ & $\begin{array}{l}3.27 \pm 0.14 \\
3.12-3.39(3)\end{array}$ & $\begin{array}{l}5.28 \pm 0.22 \\
4.95-5.67(9)\end{array}$ & $\begin{array}{c}3.9 \pm 0.10 \\
3.83-3.97(2)\end{array}$ \\
\hline $\mathrm{OL}$ & $\begin{array}{c}10.84 \pm 0.36 \\
10.16-11.73 \\
(25)\end{array}$ & $\begin{array}{c}9.87 \pm 0.43 \\
9.08-10.71 \\
(42)\end{array}$ & $\begin{array}{c}9.03 \pm 0.65 \\
8.33-9.59(4)\end{array}$ & $\begin{array}{l}8.40 \pm 0.19 \\
8.21-8.58(3)\end{array}$ & $\begin{array}{c}11.16 \pm 0.36 \\
10.77-12.05(9)\end{array}$ & $\begin{array}{c}9.20 \pm 0.46 \\
8.87-9.52(2)\end{array}$ \\
\hline $\mathrm{DL}$ & $\begin{array}{c}8.15 \pm 0.37 \\
7.53-9.05(25)\end{array}$ & $\begin{array}{c}7.63 \pm 0.49 \\
6.65-8.60(42)\end{array}$ & $\begin{array}{c}6.30 \pm 0.52 \\
5.63-6.80(4)\end{array}$ & $\begin{array}{c}5.67 \pm 0.23 \\
5.43-5.88(3)\end{array}$ & $\begin{array}{c}8.34 \pm 0.44 \\
7.82-9.29(9)\end{array}$ & $\begin{array}{c}6.85 \pm 0.01 \\
6.84-6.86(2)\end{array}$ \\
\hline MTRL & $\begin{array}{c}5.41 \pm 0.22 \\
5.02-5.7(25)\end{array}$ & $\begin{array}{c}4.69 \pm 0.20 \\
4.34-5.01(42)\end{array}$ & $\begin{array}{c}4.12 \pm 0.40 \\
3.73-4.47(4)\end{array}$ & $\begin{array}{l}3.73 \pm 0.13 \\
3.59-3.84(3)\end{array}$ & $\begin{array}{c}5.63 \pm 0.20 \\
5.28-5.92(9)\end{array}$ & $\begin{array}{c}4.28 \pm 0.20 \\
4.14-4.42(2)\end{array}$ \\
\hline IFL & $\begin{array}{c}7.21 \pm 0.42 \\
6.49-8.27(25)\end{array}$ & $\begin{array}{c}6.64 \pm 0.44 \\
5.31-7.38(42)\end{array}$ & $\begin{array}{c}5.78 \pm 0.53 \\
5.27-6.33(4)\end{array}$ & $\begin{array}{l}4.98 \pm 0.01 \\
4.97-4.99(3)\end{array}$ & $\begin{array}{c}7.52 \pm 0.51 \\
7.04-8.79(9)\end{array}$ & $\begin{array}{c}6.16 \pm 0.09 \\
6.09-6.22(2)\end{array}$ \\
\hline AW & $\begin{array}{c}5.98 \pm 0.13 \\
5.78-6.27(25)\end{array}$ & $\begin{array}{c}5.81 \pm 0.19 \\
5.42-6.27(42)\end{array}$ & $\begin{array}{c}5.31 \pm 0.05 \\
5.24-5.35(4)\end{array}$ & $\begin{array}{c}4.81 \pm 0.12 \\
4.69-4.93(3)\end{array}$ & $\begin{array}{c}6.31 \pm 0.14 \\
6.15-6.59(9)\end{array}$ & $\begin{array}{c}5.54 \pm 0.13 \\
5.44-5.63(2)\end{array}$ \\
\hline OCW & $\begin{array}{c}7.02 \pm 0.17 \\
6.62-7.25(23)\end{array}$ & $\begin{array}{c}6.59 \pm 0.19 \\
6.28-7.04(39)\end{array}$ & $\begin{array}{c}5.98 \pm 0.16 \\
5.84-6.12(4)\end{array}$ & $\begin{array}{l}5.59 \pm 0.42 \\
5.29-5.89(2)\end{array}$ & $\begin{array}{c}7.31 \pm 0.18 \\
7.11-7.60(9)\end{array}$ & $\begin{array}{c}6.04 \pm 0.31 \\
5.82-6.26(2)\end{array}$ \\
\hline MB & $\begin{array}{c}13.30 \pm 0.27 \\
12.78-13.88 \\
(25)\end{array}$ & $\begin{array}{c}12.11 \pm 0.32 \\
11.42-12.81 \\
(41)\end{array}$ & $\begin{array}{c}11.54 \pm 0.36 \\
11.06-11.89(4)\end{array}$ & $\begin{array}{l}9.55 \pm 0.09 \\
9.47-9.64(3)\end{array}$ & $\begin{array}{c}13.74 \pm 0.41 \\
13.34-14.68(9)\end{array}$ & $\begin{array}{c}11.81 \pm 0.13 \\
11.71-11.9(2)\end{array}$ \\
\hline BOL & $\begin{array}{c}2.15 \pm 0.13 \\
1.91-2.35(24)\end{array}$ & $\begin{array}{c}2.16 \pm 0.22 \\
1.81-2.69(42)\end{array}$ & $\begin{array}{c}1.79 \pm 0.36 \\
1.46-2.11(4)\end{array}$ & $\begin{array}{l}1.82 \pm 0.14 \\
1.66-1.91(3)\end{array}$ & $\begin{array}{c}2.15 \pm 0.14 \\
1.92-2.31(9)\end{array}$ & $\begin{array}{l}1.91 \pm 0.01 \\
1.9-1.91(2)\end{array}$ \\
\hline MFL & $\begin{array}{c}4.69 \pm 0.23 \\
4.18-5.17(25)\end{array}$ & $\begin{array}{c}3.70 \pm 0.25 \\
3.11-4.14(42)\end{array}$ & $\begin{array}{c}3.18 \pm 0.07 \\
3.09-3.23(4)\end{array}$ & $\begin{array}{l}4.58 \pm 2.72 \\
2.76-7.71(3)\end{array}$ & $\begin{array}{c}3.83 \pm 0.32 \\
3.31-4.44(9)\end{array}$ & - \\
\hline MFW & $\begin{array}{c}1.64 \pm 0.13 \\
1.36-1.87(25)\end{array}$ & $\begin{array}{c}1.35 \pm 0.16 \\
1.02-1.64(41)\end{array}$ & $\begin{array}{c}1.18 \pm 0.13 \\
1.03-1.34(4)\end{array}$ & $\begin{array}{l}1.03 \pm 0.05 \\
1.00-1.09(3)\end{array}$ & $\begin{array}{c}1.15 \pm 0.13 \\
0.87-1.28(9)\end{array}$ & $\begin{array}{c}0.92 \pm 0.01 \\
0.91-0.92(2)\end{array}$ \\
\hline CD & $\begin{array}{c}11.52 \pm 0.29 \\
11.01-11.97 \\
(24)\end{array}$ & $\begin{array}{c}9.19 \pm 0.32 \\
8.50-9.99(42)\end{array}$ & $\begin{array}{c}9.73 \pm 0.34 \\
9.25-10.03(4)\end{array}$ & $\begin{array}{c}8.36 \pm 0.08 \\
18.26-8.41(3)\end{array}$ & $\begin{array}{c}11.56 \pm 0.44 \\
11.01-12.48(9)\end{array}$ & $\begin{array}{c}9.98 \pm 0.03 \\
9.96-10.00(2)\end{array}$ \\
\hline ZP & $\begin{array}{c}3.27 \pm 0.17 \\
2.96-3.66(25)\end{array}$ & $\begin{array}{c}2.98 \pm 0.23 \\
2.23-3.36(42)\end{array}$ & $\begin{array}{c}2.77 \pm 0.24 \\
2.54-3.09(4)\end{array}$ & $\begin{array}{c}2.38 \pm 0.14 \\
2.30-2.54(3)\end{array}$ & $\begin{array}{c}3.27 \pm 0.18 \\
3.00-3.53(9)\end{array}$ & $\begin{array}{c}2.88 \pm 0.02 \\
2.86-2.89(2)\end{array}$ \\
\hline
\end{tabular}

the posteropalatal pits are smaller. Also, the mesopterygoid fossae in P. pearsoni is wider and U-shaped versus squarish in $P$. definitus. In $P$. pearsoni the middle lacerate foramen is more open and the procingulum of M1 is larger.

Phyllotis pearsoni is much larger than $P$. gerbillus (Table 2). Its pelage is greyer dorsally and whitish ventrally, in contrast to the yellowish dorsal pelage and whitish ventral pelage of $P$. gerbillus. The cranium of $P$. pearsoni is larger with a broader rostrum, but the interorbital region is comparatively narrower. The toothrow is longer than that of $P$. 
gerbillus (MTRL $5.41 \mathrm{~mm}$ versus $3.73 \mathrm{~mm}$ on average). The medial palatal process, absent in $P$. pearsoni, is present in $P$. gerbillus, and the middle lacerate foramen of $P$. gerbillus is more open. The capsular process of the lower incisors of $P$. pearsoni is indistinct or absent, and the coronoid process is less pronounced. The M1 is comparatively narrower, and the metaflexid $\mathrm{m} 1$ is deeper.

Figure 5. Comparisons of dorsal and ventral views of skins of Phyllotis pearsoni nov. sp. (left side, MUSM 17431), and $P$. andium (right side, MUSM 24750). Phyllotis pearsoni nov. sp. is clearly larger with a relatively shorter tail.
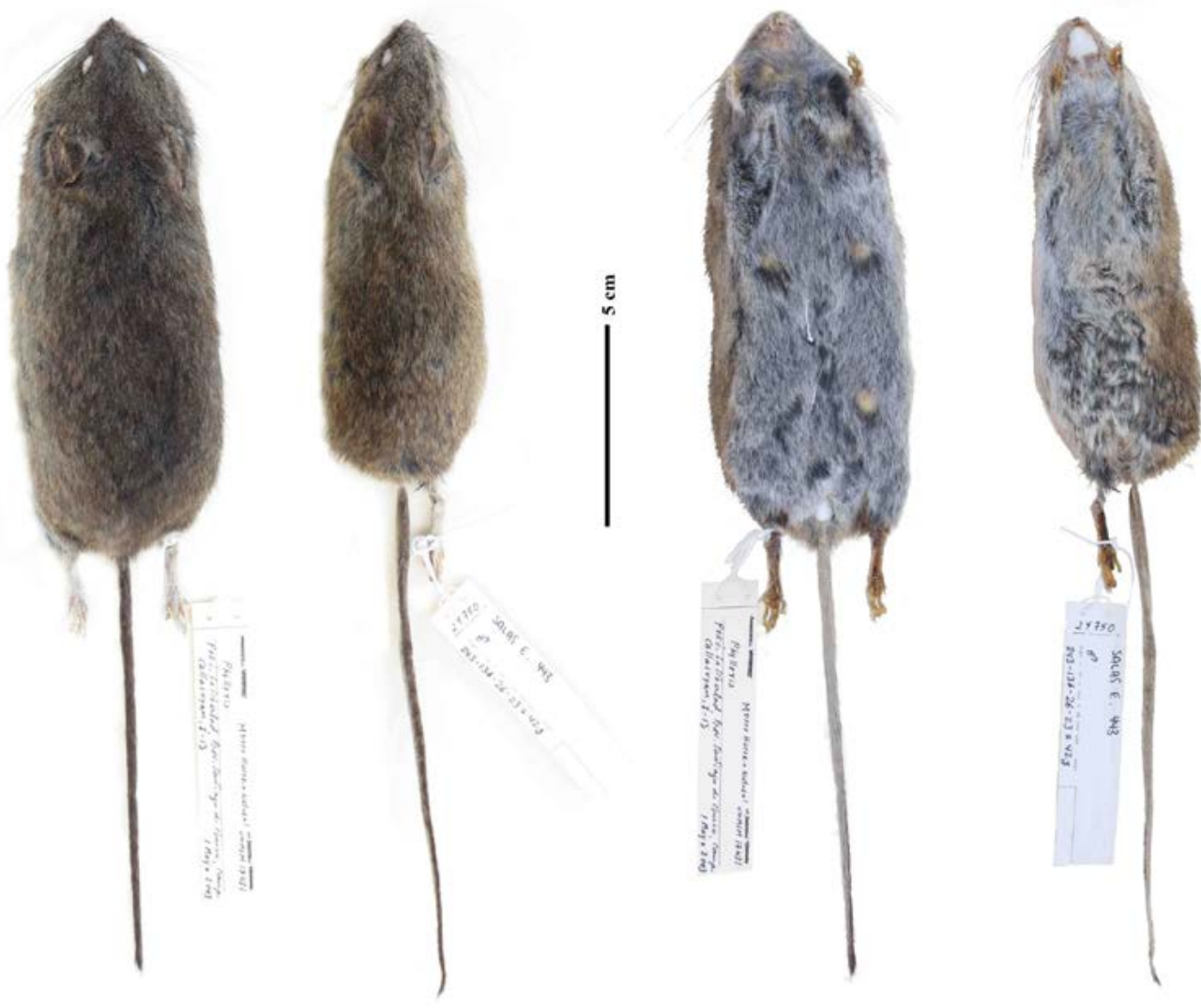

Phyllotis pearsoni is larger than $P$. haggardi (Table 2), and the hairs on dorsum are longer (17.0 mm versus $10.0 \mathrm{~mm}$ respectively). The tail of $P$. pearsoni is relatively smaller, more strongly bicolored, and lacks the small pencil present in $P$. haggardi. The cranium of $P$. pearsoni is larger with rostrum broader, the palatal bone is shorter and the posteropalatal pits are less large and deep, the mesopterygoid fossae is broader, the primary molar cusps of $P$. pearsoni are not as clearly alternate as they are in $P$. haggardi. The toothrows in $P$. haggardi converge posteriorly.

Morphometric analysis. The $t$ test showed no significant sexual dimorphism in Phyllotis pearsoni or $P$. andium, therefore both sexes were pooled for multivariate analysis. A Principal Component analysis of measurements of $P$. pearsoni and $P$. andium based on 20 cranial meristic variables found that the first three components accounted for 79.1 $\%$ of total variance $(65.4 \%, 8.0 \%$ and $5.7 \%$ respectively; Table 3$)$. The variables that account for the greatest proportion of variance are CIL, ZB, CD, OL, MFL, RL (data not showed). Plots of PC 1 versus PC 2, and PC 1 versus PC 3 show two clearly separated groups, one shaped by specimens of $P$. pearsoni and the other by specimens of $P$. andium; the new species is located mainly on the positive side of the first axis whereas $P$. andium on the negative side (Fig. 8), probably reflecting the smaller overall size of $P$. andium. A plot of PC 2 versus PC 3 (not included) shows no separation between the two species. 


\begin{tabular}{|c|c|c|c|}
\hline \multirow{2}{*}{ Variable } & \multicolumn{3}{|c|}{ Principal components } \\
\hline & First & Second & Third \\
\hline CIL & 0.97 & 0.12 & 0.01 \\
\hline ZB & 0.96 & -0.05 & 0.00 \\
\hline BB & 0.85 & -0.39 & 0.08 \\
\hline IOC & -0.27 & 0.09 & 0.81 \\
\hline RL & 0.93 & 0.04 & 0.05 \\
\hline NL & 0.89 & 0.09 & 0.07 \\
\hline RW & 0.87 & 0.26 & 0.00 \\
\hline RW2 & 0.75 & 0.16 & 0.18 \\
\hline $\mathrm{OL}$ & 0.91 & -0.02 & -0.06 \\
\hline DL & 0.72 & 0.25 & 0.17 \\
\hline MTRL & 0.89 & -0.20 & 0.10 \\
\hline IFL & 0.85 & 0.30 & 0.15 \\
\hline AW & 0.59 & 0.52 & 0.12 \\
\hline OCW & 0.79 & -0.31 & 0.04 \\
\hline $\mathrm{MB}$ & 0.89 & -0.26 & -0.11 \\
\hline BOL & 0.30 & 0.57 & -0.56 \\
\hline MFL & 0.91 & -0.17 & -0.06 \\
\hline MFW & 0.70 & -0.35 & -0.14 \\
\hline CD & 0.91 & -0.31 & -0.09 \\
\hline ZP & 0.77 & 0.35 & -0.01 \\
\hline Eigenvalue & 13.08 & 1.60 & 1.14 \\
\hline Variance \% & 65.41 & 8.02 & 5.68 \\
\hline Acumulated variance & 65.41 & 73.44 & 79.12 \\
\hline
\end{tabular}

Table 3. Factor loadings on the first three axes of a principal component analysis based on 20 log-transformed cranial variables for adult specimens of Phyllotis andium $(n=29)$ and $P$. pearsoni nov. sp. $(n=$ 23).

Natural History and Habitat. All specimens of Phyllotis pearsoni were trapped in Puna habitats of northern Peru (Fig. 9). Pacheco (2002) defined the Peruvian Puna as the region above 3,500 $\mathrm{m}$ covered by grasses and located to the south of the Huancabamba depression and between the western and eastern slopes of the Andes. Zamora-Jimeno (1996) states that the Puna or High Andean grassland is the Andean region from 3800 to 4,200 m elevation, characterized by grassland habitats with low temperatures $(<8$ ${ }^{\circ} \mathrm{C}$ isofrigid [see definition in Plant and Soil Sciences eLibrary 2014]) and water stress, summer temperatures higher than $15^{\circ} \mathrm{C}$, and annual precipitation from 250 to 1,000 $\mathrm{mm}$. In this region, grasses of the genera Calamagrostis, Festuca, Poa and others are common. In the Puna, based on a capture of 38 specimens, $P$. pearsoni showed a preference for open grassland microhabitats (63\%), followed by grassland with boulders (24\%), median size shrubs (10.5\%), and wetlands (2.5\%). 
Phyllotis pearsoni was trapped in the same Puna habitat with Akodon mollis, Akodon sp., Auliscomys pictus, Calomys sorellus, and Phyllotis andium; and was captured with Victor, Museum special and Sherman traps with standard bait consisting of oats, peanut butter, vanilla, honey, raisins, and seeds.

Figure 6. Comparisons of skulls between Phyllotis pearsoni nov. sp. on the left (MUSM 17431) and $P$. andium on the right (MUSM 23242). A) dorsal view of cranium, B) ventral view of cranium. ir: interorbital region, mlf: middle lacerate foramen, mpf: mesopterygoid fossa, nas: nasals, ps: presphenoid, za: zygomatic arch, zn: zygomatic notch, zs: zygomatic spine.

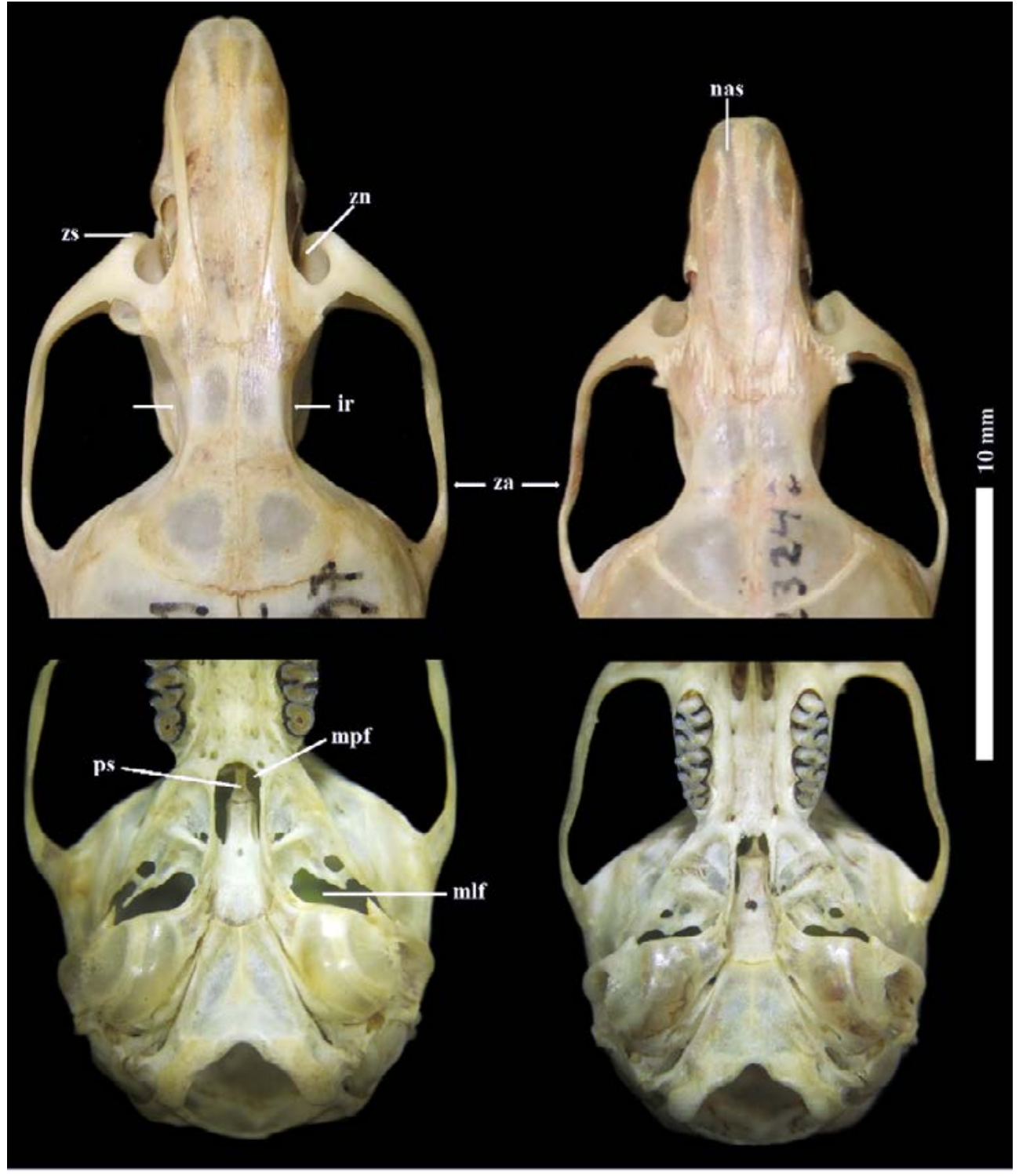

Phyllotis pearsoni showed a greater reproductive activity in the wet season (December to May) where $84 \%$ of the males with reproductive data had morphological evidence of reproductive activity assessed by the presence of scrotal testes, and $61 \%$ of females with reproductive data showed some reproductive activity (i.e., perforated vagina, mammary glands developed or lactating). These percentages of reproductive activity decreased to $67 \%$ in males and $22 \%$ in females during the dry season (June to October).

The fecal content analysis of one individual, evaluated in 10 randomly selected fields, where the percentage was interpreted as a measure of volume (Solari 1997), revealed a high abundance of fruits (70\%), including fruit remains $(54.7 \%)$ and seeds $(15.3 \%)$, followed by other plant remains $(18 \%)$, and a small percentage of insect larvae remains $(3.3 \%$; Fig. 10), 8.7\% were undetermined material. Seeds were identified as a morphospecies 
of the family Ericaceae, probably Gaultheria sp. (Cervantes, O. K., pers. comm.). Similar results interpreted as volume were obtained with the stomach content analysis of two individuals, evaluated in 10 randomly selected fields, which revealed a predominance of plant material $(78.5 \%)$ that included monocotyledons $(33.98 \%)$ and dicots $(44.47 \%)$, the last composed mainly of fruits (43.39\%) of the family Ericaceae. Insect remains were found also in low percentages: arthropod-larvae (9.06\%) and arthropod-adult (8.74\%); and some $3.75 \%$ was represented by remains of hairs, sporocarps of mycorrhizal fungi, and undetermined material (Alvarez, J. D. and Cervantes, O. K., pers. comm.).
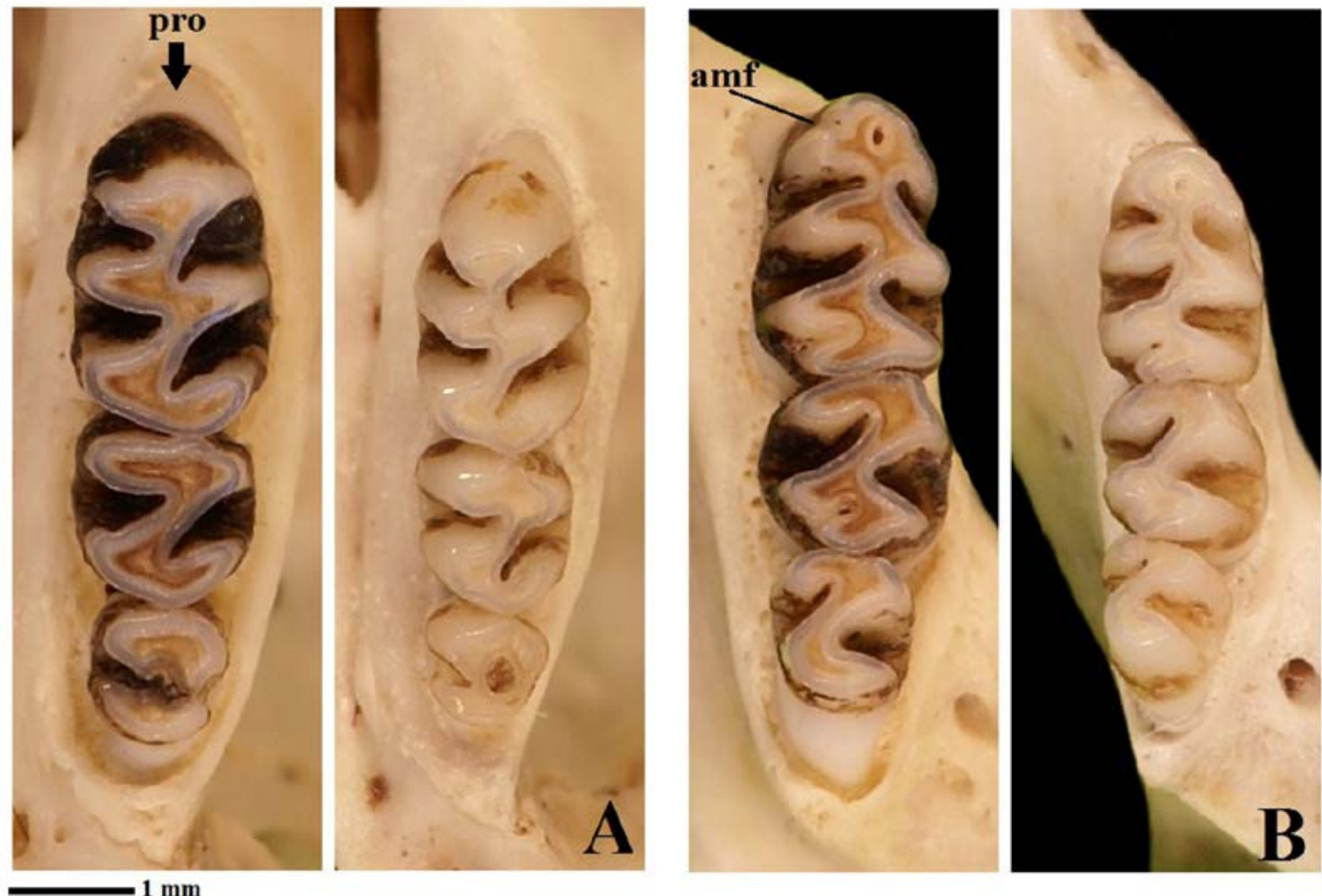

Figure 7. Comparisons of upper molar rows (A) and lower molar rows (B) between Phyllotis pearsoni nov. sp. on the left (MUSM 17431) and $P$. andium on the right (MUSM 24131). pro: procingulum, amf: anteromedian flexid.

\section{Discussion}

Peru holds a large diversity of mammalian species, ranking fifth worldwide and third in the Neotropics (Pacheco et al. 2009); moreover, new species plus distributional and taxonomic changes are constantly being reported. In rodents, for example, Akodon josemariarguedasi was recently described (Jiménez et al. 2013); Oecomys paricola was reported for first time for the country (Hice and Velazco 2012); Akodon baliolus is now recognized as full species (Pacheco et al. 2011; Coyner et al. 2013), as are A. surdus (Coyner et al. 2013) and Oxymycterus juliacae (Pacheco et al. 2011). Rhipidomys latimanus was also added to the country's fauna (Tribe 1996, Tribe in press). At present, the diversity of Peruvian rodents is no less than 168 species, six more than reported by Pacheco et al. (2009).

Steppan et al. (2007) highlighted the presence of probable cryptic species in Phyllotis. Deep topographic features in the Andes that have acted as barriers favor a high level of speciation in sigmodontine rodents (Hershkovitz 1962). With the present description of $P$. pearsoni, the current count for the genus is 16 species; but the actual diversity of the genus is expected to rise as suggested by the recent discoveries in poorly known areas: 
P. anitae and P. alisosiensis, both from Argentina (Jayat et al. 2007; Ferro et al. 2010, respectively); and $P$. pearsoni (this work).

Steppan et al. (2007) based on a molecular analysis of Phyllotis species using cyt $b$, found that $P$. pearsoni (reported as Phyllotis sp. nov. 1 ) was closely related to $P$. andium, $P$. amicus and $P$. gerbillus, members of the "andium/amicus group," a monophyletic group with a distributional range restricted to northwestern Peru and southern Ecuador. Other species that occur within the distribution of this group are $P$. haggardi and $P$. definitus (Pearson 1958). Unfortunately, these species were not included in Steppan et al. (2007)'s analysis, and consequently it is uncertain whether these species belong to the andium/ amicus group. A systematic study including $P$. haggardi and $P$. definitus is needed to test the hypothesis that North-Andean Phyllotis species are a monophyletic group.

Figure 8. Projection of specimen scores for factors 1 and 2 (above) and factors 1 and 3 (below) extracted from principal component analyses, comparing samples of Phyllotis andium and Phyllotis pearsoni nov. sp. See Table 3 for variable correlations and explanation of percent variance.
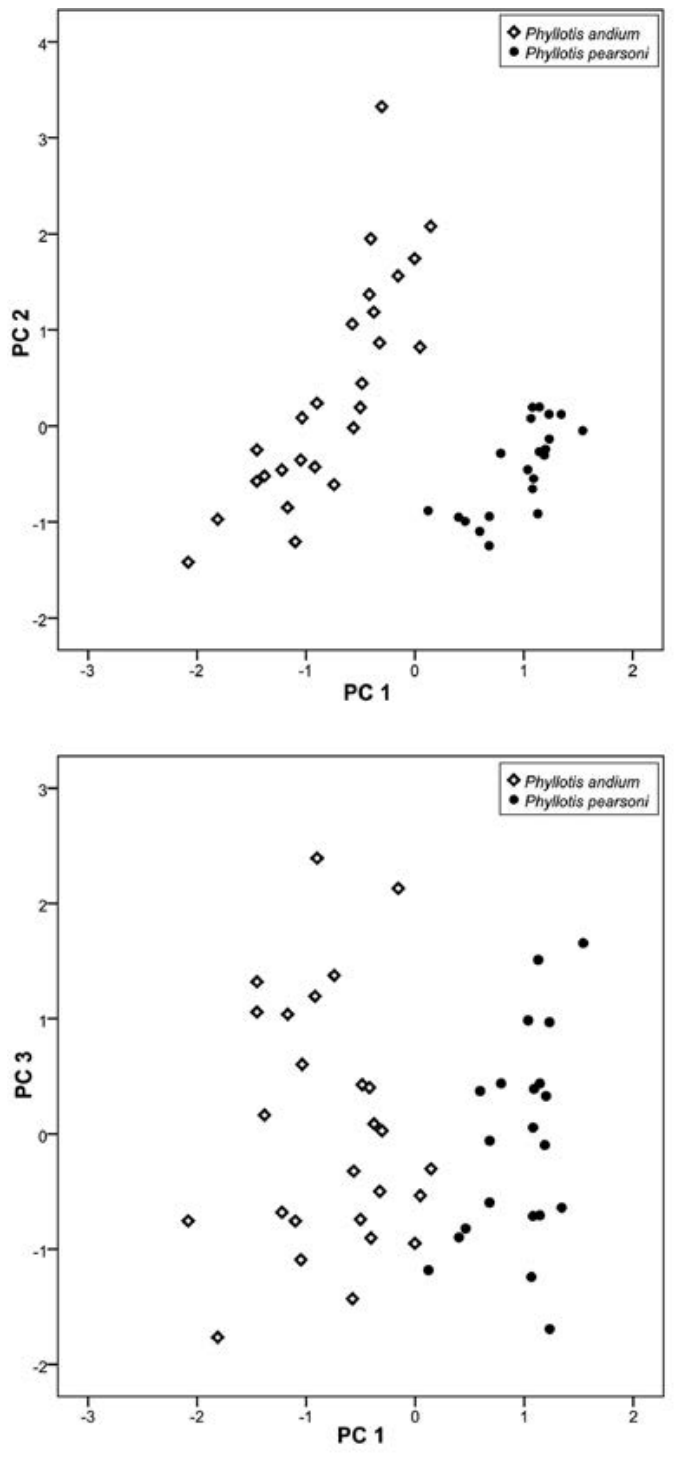

Phyllotis pearsoni is an endemic Peruvian species (Pacheco et al. 2009) that occurs only on the western Andes in Northern Peru. Based on present records we hypothesize that the distributional limits of this species are the Río Santa to the south, Río Marañón to the east, and the Huancabamba depression to the north. These geographic features are barriers to bird species (Vuilleumier 1969; Parker et al. 1985; Schulenberg et al. 2007, 
amphibians and reptiles (Duellman 1979; Cannatella 1982; Cadle 1991; Duellman and Wild 1993), and other mammals (Patterson et al. 1992, Pacheco 2002); and are also likely geographic barriers for $P$. pearsoni. Other species are known to have ranges similar to P. pearsoni including the akodontines Akodon nov. sp. (Pacheco et al. 2009) and Akodon mollis (Jiménez et al. 2013), and the thomasomyines Thomasomys praetor and T. pyrrhonotus (Pacheco in press). The concordance of these ranges of species from different tribes suggest that the western Andean Cordillera in Northern Peru might represent a center of endemism for rodents and likely other taxa.

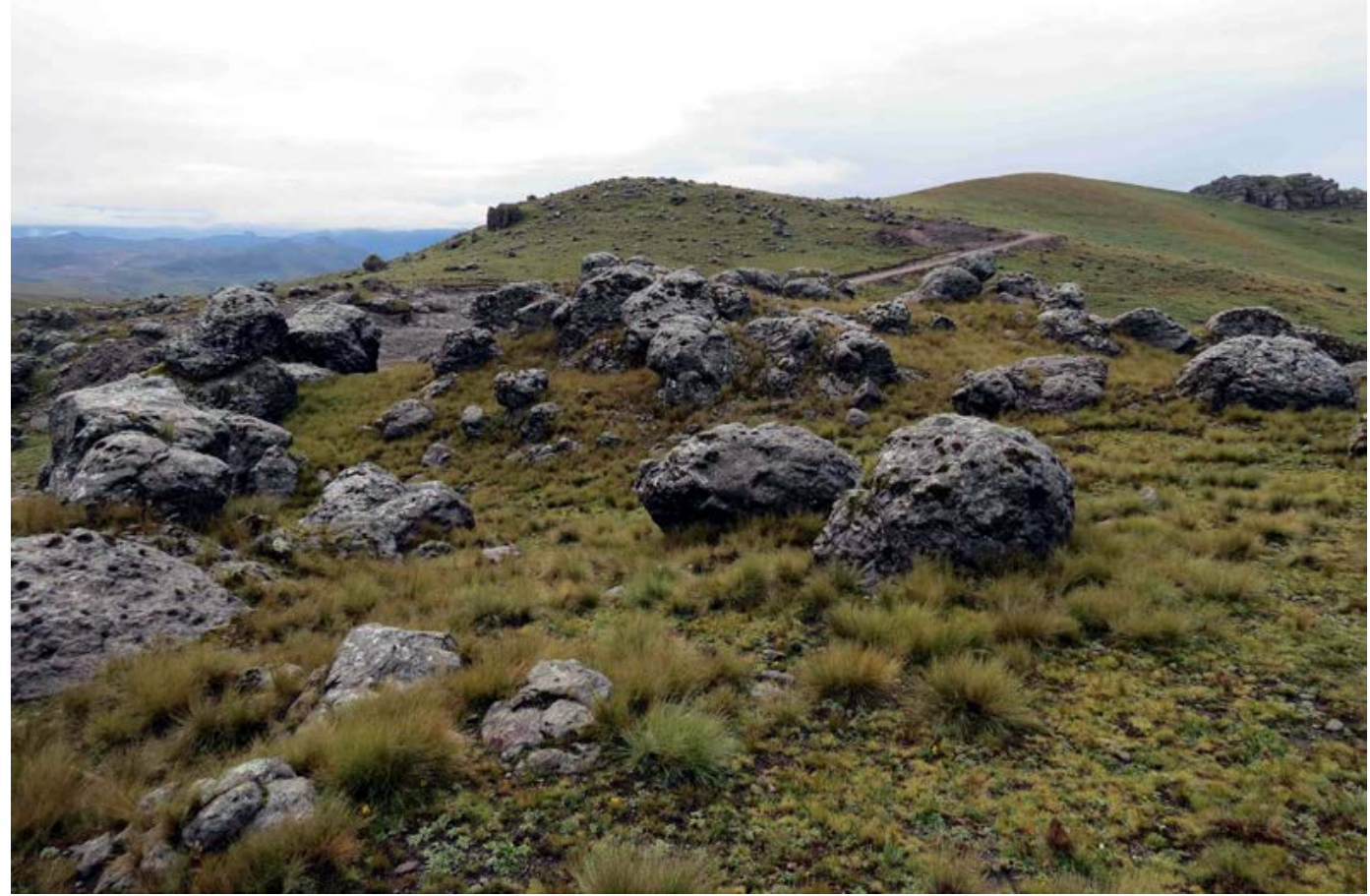

Figure 9. Puna habitat in the Quiruvilca region, La Libertad Department, Peru, where Phyllotis pearsoni nov. sp. was collected. Photograph by V. Pacheco.

Phyllotis pearsoni and $P$. andium are closely related and sympatric species, but they are distinct in morphology, karyotype, and DNA sequences. Steppan et al. (2007: 813) found six apomorphic changes: four unique synapomorphies for $P$. pearsoni, and two for $P$. andium; morphological and karyotype data were presented here. Studies on the habitat preferences and ecological topics that may explain the causes of speciation are scarce (Arana et al. 2002; Cerro 2005). P. pearsoni has been recorded only in the Puna habitats of northern Peru above 3,500 m; in contrast, $P$. andium has been recorded in more diverse habitats including coastal desert, Paramo, shrubby and Puna habitats (Pacheco et al. 2009), with preference for shrubby habitats (Pearson 1972; Cerro 2005), from approximately $200 \mathrm{~m}$ to $4,800 \mathrm{~m}$ (Hershkovitz 1962). It thus appears that $P$. andium is a more generalist species than $P$. pearsoni. P. gerbillus $(0 \mathrm{~m}$ to $120 \mathrm{~m}$ ) and $P$. amicus $(85$ $\mathrm{m}$ to $3,200 \mathrm{~m}$ ), other members of the andium/amicus group, also have a much lower elevational range. Based on Steppan et al. (2007: 808, Fig. 2) it is then possible that highland species like $P$. pearsoni derived from lowland and probably more generalist species. Ecological and natural history studies are needed to test whether lowland species are more generalists than highland species. 
The karyotype of $P$. pearsoni $(2 \mathrm{n}=48, \mathrm{FN}=72)$ is more similar to the karyotype of $P$. andium $(2 \mathrm{n}=64, \mathrm{FN}=72$; Pearson 1972), sharing the presence of numerous acrocentric chromosomes, a feature that appears to reinforce the close relationship of these species suggested by their DNA sequences (Steppan et al. 2007). P. definitus was not included in that study because of lack of tissues. However, we hypothesize that $P$. definitus $(2 \mathrm{n}=$ $54, \mathrm{FN}=72$ ) might be closely related to $P$. andium and $P$. pearsoni based on the presence of acrocentric chromosomes. Together these species form a group that we propose to call the andium group, in a more restricted sense than the andium/amicus or andium/ gerbillus group (sensu Steppan et al. 2007). The restricted andium clade is found to be related to the clade of $P$. gerbillus and $P$. amicus in a phylogeny based on cytochrome $b$, but not with RAG-1 sequences (Steppan et al. 2007). Banding techniques are needed to properly assess the close relationship of the species that share acrocentric chromosomes

Figure 10. Fecal sample analysis of Phyllotis pearsoni nov. sp. A) Seeds of probably Gaultheria sp., B) Plant material (fruit skins and vascular tissues).
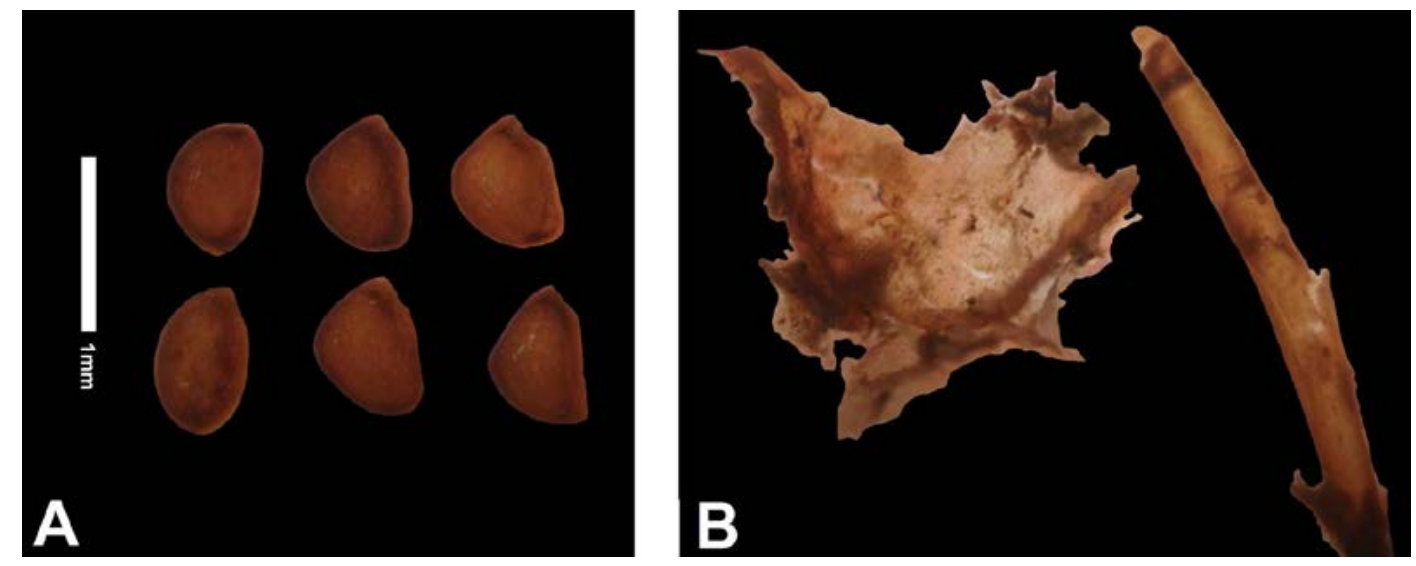

Although sharing numerous acrocentric chromosomes is not a proof of relationship per se, several works within Phyllotini show that its diversity in chromosomal complement is derived from the ancestral karyotype of $P$. osilae (Kramer et al. 1999) through a reduction in diploid number and increase in fundamental number (Spotorno et al. 2001). Within the andium group, we suggest that the chromosomal complement of $P$. pearsoni has resulted from three autosomic fusions (Robertsonian translocations) and a reduction of the $Y$ chromosome from the karyotype of $P$. definitus (Fig. 11), a common process that favors reproductive isolation and speciation (Walker et al. 1984). The derivation of the chromosomal complement of $P$. pearsoni from $P$. andium or $P$. osilae is less parsimonious because it would require eight and thirteen autosomic fusions respectively. The karyotype of $P$. pearsoni then suggests that it is more related to $P$. definitus than to other members of the andium group. Our report of the karyotype of $P$. pearsoni supports Pearson's hypothesis (1972) that the evolution of Phyllotis has been accompanied by a series of Robertsonian translocations, a process similar to the chromosome evolution found in akodontine rodents (Fernández-Donoso et al. 2001)

The stomach morphology of Phyllotis pearsoni is very similar to that of other species of Phyllotis as illustrated for $P$. osilae by Dorst (1972: Fig. 1), who remarked that that species is also similar to another phyllotine, Auliscomys pictus. These rodents differ then slightly from the phyllotine Graomys griseoflavus (Carleton 1973: Fig. 2C) in the extension of the glandular stomach toward the corpus. Unfortunately, stomach morphologies of few 
phyllotines have been analyzed; however the reported variation in this organ suggest that there is likely phylogenetic signal and should be further studied.

Although our diet analysis is preliminary, Phyllotis pearsoni appears to be an herbivorous rodent that prefers to feed on fruit items, unlike Phyllotis andium that consumes mainly grasses (Pizzimenti and De Salle 1980; Cerro 2005). Thus these sympatric species may not overlap in their diets. Pizzimenti and De Salle (1980) suggested that larger species are more herbivorous than smaller species, which are more insectivorous. The herbivorous diet of the comparatively large species $P$. pearsoni agrees with this prediction.

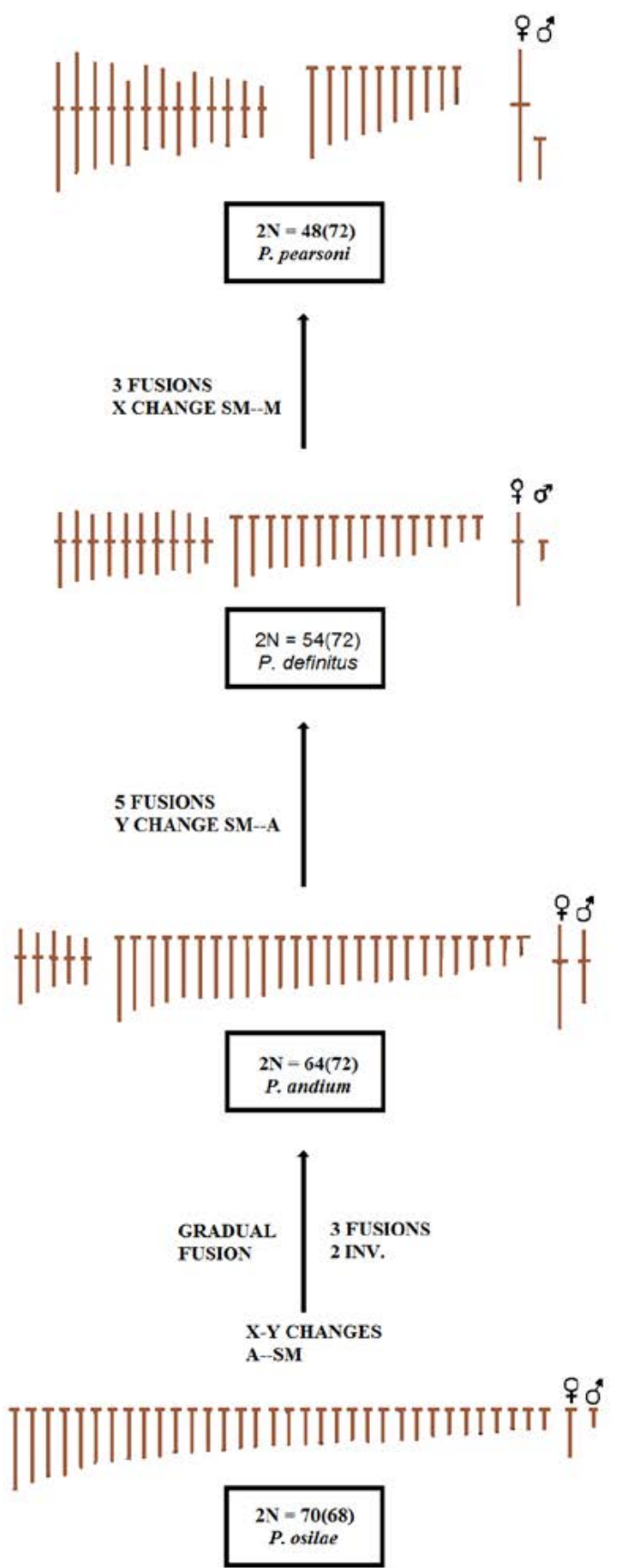

Figure 11. Hypothetical chromosome evolution in the species member of the Phyllotis andium group.

The localities where $P$. pearsoni has been registered are not in any protected area. The closest protected area of significant size is the Huascarán National Park in the Cordillera 
Blanca, department of Ancash, but no record of this species exists from that Park, and according to the range we project for $P$. pearsoni, it likely does not occur there. The Coto de Caza Sunchubamba, a protective area of lower category of 59,735 ha created to favor hunting of white tail deer and foxes, is located in Cajamarca Department and has an elevational range from 950 a 4,200 m (Sumaqperu 2013). It is likely that $P$. pearsoni is present in the upper limit of CC Sunchubamba, but no diversity assessment is available. The Calipuy National Reserve, a relatively small protected area of 64,000 ha in La Libertad Department with an elevational range of 800 to 3,900 m, is characterized by shrubby steppe and cactacea habitats that appear unsuitable for the species (Wikipedia 2013a). However, Calipuy National Sanctuary (see Wikipedia 2013b), also in La Libertad Department between 3,600 and 4,300 m, has appropriate Puna and Paramo habitats, but encompasses too small a protected area (4,500 ha) to insure the continuity of this species. The species may be threatened given its restricted distribution, the relatively high anthropic activity in the region, and its absence in any protected area. We also suggest that Calipuy National Sanctuary be increased in size and that an inventory assessment be undertaken to confirm that $P$. pearsoni is present.

\section{Acknowledgements}

We thank H. Quintana, A. Vásquez, and L. M. Villalobos for field assistance, and to M. Del Alcázar for a bone marrow preparation in the field. We acknowledge also to J. L. Patton (The Museum of Vertebrate Zoology, University of California, Berkeley) for kindly supporting ER to visit the Museum of Vertebrate Zoology collection for supplemental comparisons of Phyllotis species. Our thanks also to O. K. Cervantes and J. D. Alvarez for the stomach content and fecal analyses. Finally, we thank the associate editor and three anonymous reviewers for providing valuable inputs, suggestions, and grammar corrections that helped to improve this work.

\section{References}

Abdala, F., and M. M. Díaz. 2000. Anatomia craneana de Akodon albiventer (Rodentia, Muridae, Sigmodontinae). Iheringia, Série Zoologia 88:33-50.

Arana, M., O. Ramírez, S. Santa María, C. Kunimoto, R. Velarde, C. De La Cruz, and M. Ruiz. 2002. Densidad poblacional y Reproducción de dos Ratones orejudos del Perú. Revista Chilena de Historia Natural 75:751-756.

BraUN, J. K. 1993. Systematic relationships of the tribe Phyllotini (Muridae: Sigmodontinae) of South America. Special Publication Oklahoma Museum of natural, History, Norman 1-50.

CAdLE, J. E. 1991. Systematics of lizards of the genus Stenocercus (Iguania: Tropiduridae) from northern Peru: new species and comments on relationships and distribution patterns. Proceedings of the Academy of Natural Sciences of Philadelphia 143:196.

Cannatella, D. C. 1982. Leaf-frogs of the Phyllomedusa perinesos group (Anura: Hylidae). Copeia 1982:501-513.

Carleton, M. D. 1973. A survey of gross stomach morphology in New World Cricetinae (Rodentia, Muroidea) with comments on functional interpretations. Miscellaneous Publications of the Museum of Zoology, University of Michigan 146:1-43. 
Carleton, M. D. 1980. Phylogenetic Relationships in Neotomine-Peromyscine Rodents (Muridea) and a Reappraisal of the Dichotomy within New World Cricetinae. Miscellaneous Publications Museum of Zoology, University of Muchigan 157:1146.

Carleton, M. D., And G. G. Musser. 1989. Systematic studies of Oryzomyine rodents (Muridae, Sigmodontinae): a synopsis of Microryzomys. Bulletin of the American Museum of Natural History 191:1-83.

Cerro R. 2005. Ecología poblacional comparada entre un roedor nativo y uno introducido en dos microhábitats en las Lomas de Lachay. Tesis para optar el Título de Licenciado en Ciencias con mención en Biología. Facultad de Ciencias y Filosofía. Universidad peruana Cayetano Heredia. Lima, Perú.

Coyner, B. S., J. K. Braun, M. A. Mares, and R. A. Van Den Bussche. 2013. Taxonomic validity of species groups in the genus Akodon (Rodentia, Cricetidae). Zoologica Scripta 42:335-350.

Crespin, L. ANd M. Lima. 2006. Supervivencia adulta y dinámica poblacional del lauchón orejudo Phyllotis darwini en Chile central. Revista Chilena de Historia Natural 79:295-308.

Dorst, J. 1972. Morphologie de l'estomac et regime alimentaire de quelques rongeurs des hautes andes du perou. Mammalia 36:647-656.

Duellman, W. E. 1979. The herpetofauna of the Andes: patterns of distribution, origin, differentiation, and present communities. Monograph of the University of Kansas Museum of Natural History 7: 371-459.

Duellman, W. E., and E. R. Wild. 1993. Anuran amphibians from the Cordillera de Huancabamba, northern Peru: systematics, ecology, and biogeography. Occasional Papers of the Museum of Natural History University of Kansas 157:1-53.

Fernández-Donoso, R., S. Berrios, J. Page, M. S. Merani, M. S. Lizarralde, L. Vidal-Rioja, AND N. Bianchi. 2001. Robertsonian chromosome polymorphism of Akodon molinae (Rodentia: Sigmodontinae): analysis of trivalents in meiotic prophase. Revista Chilena de Historia Natural 74:107-119.

Ferro, L. I., J. J. Martínez, and R. M. Barquez. 2010. A new species of Phyllotis (Rodentia, Cricetidae, Sigmodontidae) from Tucumán province, Argentina. Mammalian Biology 75:523-537.

Ford, C.E., AND J. L. Hamerton. 1956. A colchicine, hypotonic citrate, squash sequence for mammalian chromosomes. Stain Technology 31:247-251.

Hershkovitz, P. 1962. Evolution of Neotropical cricetine rodents (Muridae) with special reference to the phyllotine group. Fieldiana: Zoology 46:1-524.

Hershrovitz, P. 1994. The Description of a New Species of South American Hocicudo, or Long-Nose Mouse. Genus Oxymycterus (Sigmodontinae, Muroidea), with a critical review of the generic content. Fieldiana, Zoology, new series 79:1-43.

Hice, C. L., and P. M. Velazco. 2012. The Non-volant Mammals of the Reserva Nacional Allpahuayo-Mishana, Loreto, Peru. Special Publications of the Museum of Texas Tech University 60:1-135.

Jayat, J. P., G. D’Elía, U. F. J. Pardiñas, and J. G. Namen. 2007. A new species of Phyllotis (Rodentia, Cricetidae, Sigmodontinae) from the upper montane forest of the Yungas of northwestern Argentina. Pp. 775-798 in The Quintessential Naturalist: Honoring 
the Life and Legacy of Oliver P. Pearson (Kelt, D. A., E. Lessa, J. A. Salazar-Bravo, and J. L. Patton, eds.). University of California Publications, Zoology Volume 134:1-981.

Jiménez, C. F., V. Pacheco, and D. Vivas. 2013. An introduction to the systematics of Akodon orophilus Osgood, 1913 (Rodentia: Cricetidae) with the description of a new species. Zootaxa 3669:223-242.

Kramer K. M., J. A. Monjeau, E. C. Birney, and R. S. Sikes. 1999. Phyllotis xanthopygus. Mammalian Species. 617:1-7.

Levan, A., K. Fredga, and A. A. Sandberg. 1964. Nomenclature for centromeric position on chromosomes. Hereditas 52:201-220.

López-Cortés, F., Cortés A., E. Miranda, and J. R. Rau. 2007. Dietas de Abrothrix andinus, Phyllotis xanthopygus (Rodentia) y Lepus europaeus (Lagomorpha) en un ambiente altoandino de Chile. Revista Chilena de Historia Natural 80:3-12.

Musser, G. M., And M. D. Carleton. 2005. Superfamily Muroidea. Pp 894-1531 in Mammal species of the world: A taxonomic and geographic reference Third ed. (Wilson, D. E., and D. M. Reeder. eds.). Johns Hopkins University Press. Baltimore, USA.

Myers, P., J. L. Patton, and M. F. Smith. 1990. A review of the boliviensis group of Akodon (Muridae: Sigmodontinae) with emphasis on Peru and Bolivia. Miscellaneous Publications Museum of Zoology University of Michigan 177:1-89.

Pacheco, V. 2002. Mamíferos del Perú. Pp. 503-550 in Diversidad y conservación de los mamíferos neotropicales (Ceballos, G., and J. Simonetti. eds). CONABIOUNAM. Ciudad de México, Mexico.

Pacheco, V. 2003. Phylogenetic analyses of the Thomasomyini (Muroidea: Sigmodontinae) based on morphological data. Ph D. dissertation. The City University New York. New York, USA.

Pacheco V. In Press. Genus Thomasomys Coues, 1884. In Mammals of South America. Volume 2, Rodents (Patton, J. L., U. F. J. Pardiñas, and G. D'Elía, eds.). The University of Chicago Press. Chicago, USA.

Pacheco V., G. Márquez, E. Salas, and O. Centty. 2011. Diversidad de mamíferos en la cuenca media del río Tambopata, Puno, Perú. Revista Peruana de Biología 18:231-244.

Pacheco, V., R. Cadenillas, E. Salas, C. Tello, and H. Zeballos. 2009. Diversidad y endemismo de los mamíferos del Perú, Revista Peruana de Biología 16:5-32.

Pardiñas, U. F. J., D. E. Udrizar Sauthier, and P. Teta. 2009. Roedores del extremo sudoriental Continental de Argentina. Mastozoología Neotropical 16:471-473.

Parker III, T. A., T. S. Schulenberg, G. R. Graves, and M. J. Braun. 1985. The avifauna of the Huancabamba region, northern Peru. Ornithological Monographs 36:169197.

Patterson, B. D., V. Pacheco, and M. V. Ashley. 1992. On the origins of the western slope region of endemism: systematics of fig-eating bats, genus Artibeus. Pp. 189-205 in Biogeografía, Ecología y conservación del bosque montano en el Perú (Young, K. R., and N. Valencia, eds.). Memorias del museo de Historia Natural volumen 21, Universidad Nacional Mayor de San Marcos. Lima, Perú. 
Pearson, O. P. 1958. A taxonomic revision of the rodent genus Phyllotis. University of California, Publications in Zoology 56:391-477.

Pearson, O. P. 1972. New information on ranges and relationships within the rodent genus Phyllotis in Peru and Ecuador. Journal of Mammalogy 53:677-686.

Pearson, O. P., and J. L. Patton. 1976. Relationships among South American phyllotine rodents based on chromosome analysis. Journal of Mammalogy 57:339-350.

Pearson, O. P., And C. P. Ralph. 1978. The diversity and abundance of vertebrates along an altitudinal gradient in Peru. Memorias del Museo de Historia Natural "Javier Prado" 18:1-97.

Pizzimenti, J. J., and R. De Salle. 1980. Dietary and morphometric variation in some Peruvian rodent communities: the effect of feeding strategy on evolution. Biological Journal of the Linnean Society 13:263-285.

Plant \& Soll Sciences elibrary. 2014. Soil Genesis and Development, Lesson 6 - Global Soil Resources and Distribution [Access date 1 May 2014] <http://passel.unl.edu/ pages/informationmodule.php?idinformationmodule=1130447033\&topicorder $=1$ $2 \& \operatorname{maxto}=12 \& \operatorname{minto}=1>$

ReIG, O. A. 1980. A new fossil genus of South American cricetid rodents allied to Wiedomys with an assessment of the Sigmodontinae. Journal of Zoology 192:257281.

Salazar-Bravo, J., U. F. J. Pardiñas, and G. D'elía. 2013. A phylogenetic appraisal of Sigmodontinae (Rodentia, Cricetidae) with emphasis on phyllotine genera: systematics and biogeography. Zoologica Scripta 42:250-261.

Schulenberg, T. S., D. F. Stotz, D. F. Lane, J. P. O'Neill, J. P., and T. A. Parker III. 2007. Birds of Peru. Princeton University Press. New Jersey, USA.

Smithe, F. B. 1975. Naturalist's color guide. American Museum of Natural History. New York. USA.

Soları, S. 2007. Trophic relationships within a Highland rodent assemblage from Manu National Park, Cusco, Peru. Pp. 225-240 in The Quintessential Naturalist: Honoring the Life and Legacy of Oliver P. Pearson (Kelt, D. A., E. Lessa, J. A. Salazar-Bravo and J. L. Patton, eds.). University of California Publications, Zoology Volume 134:1-981.

Spotorno, A., L. Walker, S. Flores, M. Yevenes, and M. J. Zuleta. 2001. Evolución de los filotinos (Rodentia, Muridae) en los Andes del Sur. Revista Chilena de Historia Natural 74:151-166.

Steppan, S. J. 1995. Revision of the tribe Phyllotini (Rodentia: Sigmodontinae), with a phylogenetic hypothesis for the Sigmodontinae. Fieldiana: Zoology, new series 80:1-112.

StepPan, S. J. 1998. Phylogenetic relationships and species limits within Phyllotis (Rodentia: Sigmodontinae): concordance between mtDNA sequence and morphology. Journal of Mammalogy 79:573-593.

Steppan, S. J., O. Ramirez, J. Banbury, D. Huchon, V. Pacheco , L. I. Walker, and A. E. SPOTORNo. 2007. A molecular reappraisal of the systematics of the leaf-eared mice Phyllotis and their relatives. Pp. 799-826 in The Quintessential Naturalist: Honoring the Life and Legacy of Oliver P. Pearson (Kelt, D. A., E. Lessa, J. A. 
Salazar-Bravo, and J. L. Patton, eds.). University of California Publications, Zoology Volume 134:1-981.

SumaQPeru. 2013. Coto de Caza Sunchubamba [Access date November 2013] <http:// wiki.sumaqperu.com/es/Coto_de_Caza_Sunchubamba>

Tribe, C. J. 1996. The Neotropical rodent genus Rhipidomys (Cricetidae; Sigmodontinae) - a taxonomic revision. Ph. D. dissertation, University College London. London, United Kingdom.

Trıbe, C. J. In press. Genus Rhipidomys Tschudi, 1845. In Mammals of South America. Volume 2, Rodents (Patton, J. L., U. F. J. Pardiñas, and G. D'Elía, eds.) The University of Chicago Press. Chicago, USA.

Voss, R. S. 1988. Systematics and ecology of Ichthyomyine rodents (Muroidea): patterns of morphological evolution in a small adaptative radiation. Bulletin of the American Museum of Natural History 188:259-493.

Voss R. S. 1991. An introduction to the Neotropical Muroid Rodent genus Zygodontomys. Bulletin of the American Museum of Natural History 210:1-113

Voss, R. S. 1993. A revision of the Brazilian muroid rodent genus Delomys with remarks on "Thomasomyine" characters. American Museum Novitates 3073:1-44.

Voss, R. S., and M. D. Carleton. 1993. A new genus for Hesperomus molitor Winge and Holochilus magnus Hershkovitz (Mammalia, Muridae) with an Analysis of its Phylogenetic Relationships. American Museum Novitates 3085:1-39.

Vuilleumier, F. 1969. Pleistocene speciation in birds living in the high Andes. Nature 223:1179-1180.

Walker, L. I., A. E. Spotorno, and J. Arrau. 1984. Cytogenetic and Reproductive Studies of two nominal Subspecies of Phyllotis darwini and their experimental Hybrids. Journal of Mammalogy 65:220-230.

Wiluams, M. 1990. Notas sobre reproducción de Phyllotis amicus Thomas (Rodentia: Cricetidae) en el campo y laboratorio. Biota (Perú) 96:9-17.

WikıPedia. 2013a. Reserva nacional de Calipuy [Access date November 2013] <http:// es.wikipedia.org/wiki/Reserva_nacional_de_Calipuy>.

WiKıPedia. 2013b. Santuario nacional de Calipuy [Access date November 2013] <http:// es.wikipedia.org/wiki/Santuario_nacional_de_Calipuy>.

Zamora-Jimeno, C. 1996. Las regiones ecológicas del Perú. Pp. 137-141 in Diversidad Biológica del Perú, Zonas prioritarias para su conservación (Rodríguez L. O., ed.). FANPE- GTZ, INRENA. Lima, Peru.

Sometido: 2 de enero de 2014

Revisado: 17 de mayo de 2014

Aceptado: 16 de junio de 2014

Editor asociado: Robert Owen

Diseño gráfico editorial: Gerardo Hernández 
The following list includes all specimens examined in this study, with their respective localities and acronyms. Specimens in brackets were used in the distribution map, and those with an asterisk in the morphometric analysis. See Materials and Methods for abbreviations:

Phyllotis amicus ( $n=12)$. PERU: Cajamarca; El Arenal, $1 \mathrm{~km} \mathrm{~S}$ and $6 \mathrm{~km} \mathrm{~W}$ Pomahuaca $-6^{\circ}$ 7' 44" S, -79 3' 25.992" W (MVZ 135721*, 135722*); Ancash: 29 km S (by road), Casma $-9^{\circ} 42^{\prime} 23.47^{\prime \prime}$ S, -78 $16^{\prime} 25.21^{\prime \prime}$ W (MVZ 139262*, 139263*); Huaylas, Huallanca, Huallanca $-8^{\circ} 49^{\prime} 8.47^{\prime \prime}$ S, $-77^{\circ} 51^{\prime} 45.25^{\prime \prime}$ W (MUSM 2439 - 2442); Huarmey, Lomas de Lupin $-10^{\circ} 22^{\prime} 0.12^{\prime \prime}$ S, $-77^{\circ} 55^{\prime}$ 59.88" W (MUSM 2448); La Libertad: Valle del Moche (MUSM 2443); Camino a Otuzco (MUSM 2449); Lima: Cerro San Gerónimo (MUSM 2438).

Phyllotis andium $(n=48)$. PERU: Ancash: Pallasca, Conchuco, Buena Vista $-8^{\circ} 16^{\prime}$ 55.06" S, $-77^{\circ} 51^{\prime}$ 6.16" W (MUSM 4531*, 4532*, 4579*); Pallasca, Conchucos, Laguna Llamacocha $-8^{\circ} 14^{\prime} 55.32^{\prime \prime}$ S, $-77^{\circ} 49^{\prime} 1.02^{\prime \prime}$ W (MUSM 23230*, 23231*); Pallasca, Conchucos, Quebrada Chalhuacocha, Laguna Magullo Chico -8 ${ }^{\circ} 15^{\prime} 13.61^{\prime \prime}$ S, $-77^{\circ} 48^{\prime}$ $0.04^{\prime \prime}$ W (MUSM 23234*, 23235*); Pallasca, Conchucos, Quebrada Toldobamba $-8^{\circ} 14^{\prime}$ 39.01" S, $-77^{\circ} 49^{\prime} 49.26^{\prime \prime}$ W (MUSM 23236*); Pallasca, Quebrada Toldobamba, Vivero Cumbal $-8^{\circ} 15^{\prime}$ 9.76" S, $-77^{\circ} 49^{\prime}$ 43.5" W (MUSM 23238*, 23239*, 23240*, 23241*, 23242*, 23243); La Libertad: Daniel A. Carrión, Huamachuco, La Arena -7 52' 30.14" S, -78 8' 28.75" W (MUSM 24127*, 24128*, 24129*, 24130*, 24131, 24132, 24133, 24134*, 24159, 24160*, 24161*, 24162*, 24163*, 24164*, 24165*, 24166); Otuzco, Usquil, Coina (cuenca del Río Perejil, ca. Hostería El Sol) -7 48' 12.67" S, -78²2' 4.26" W (MUSM 24900*); Sánchez Carrión, Sanagorán, Sanagorán, Río Chuyuhual $-7^{\circ} 47^{\prime}$ 7.91" S, -78 8' 55.39" W (MUSM 24750*, 24751*, 24752*, 24753*, 24754*); Santiago

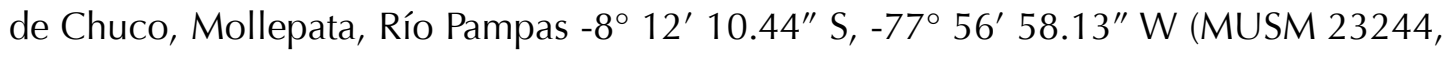
23245, 23246*); Santiago de Chuco, Mollepata, Río Pampas, Tablachaca -8 ${ }^{\circ} 12^{\prime} 10.51^{\prime \prime}$ S, -77 56' 58.24" W (MUSM 23247*); Santiago de Chuco, Quiruvilca, Quebrada Negra $-7^{\circ} 56^{\prime} 17.52^{\prime \prime}$ S, -78 12' 58.64" W (MUSM 23186); Santiago de Chuco, Quiruvilca, Lagunas Norte, Río Caballo Moro -8 2' 25.19" S, -78 13' 52.61" W (MUSM 24742*, 24743*, 24744*, 24745*, 24746*, 24747*, 24748*); Santiago de Chuco, Quiruvilca, Lagunas Norte, Río Perejil, San Pedro -7 55' 22.91" S, -78 16' 37.99" W (MUSM 24749*, 24902*).

Phyllotis gerbillus $(n=4)$. PERU: PIURA: Sechura, Médano Tres Brazos, a $10.2 \mathrm{Km}$ E de Sechura -5 33' 36.468" S, -80 43' 43.14" W (MUSM 20936*); Sechura, Cerro Illescas (MUSM 2479*, 2480*); Paita, Colán, ca. Colán (MUSM 2481*).

Phyllotis definitus $(n=10)$. PERU: Ancash: Tinco, $2 \mathrm{~km} \mathrm{~S}$ and $15 \mathrm{Km}$ W Huaraz -9 $9^{\circ} 33^{\prime} 0^{\prime \prime}$ $\mathrm{S},-77^{\circ} 40^{\prime} 0^{\prime \prime} \mathrm{W}$ (MVZ 135791*, 135792*, 135793*); 1 km N and $12 \mathrm{~km}$ E Pariacoto -9 ${ }^{\circ}$ 
30' 27.47" S, -77 46' 26.54" W (MVZ 135794*, 135795, 135797*, 135802*, 135803*, $\left.135805^{*}, 135806^{*}\right)$.

Phyllotis haggardi $(n=2)$. ECUADOR: Pichincha, $22 \mathrm{~km}$ NNE Quito, $(1 \mathrm{~km}$ NW Equator Monument) - $0^{\circ} 1^{\prime}$ 59.45" S, -78 25' 27.73" W (MVZ 139575*); Pichincha, 26 km NNE Quito $-0^{\circ} 0^{\prime} 30.08^{\prime \prime} \mathrm{N},-78^{\circ} 24^{\prime} 38.23^{\prime \prime} \mathrm{W}$ (MVZ 140054*).

Phyllotis pearsoni $(\mathrm{n}=52)$. PERU: Ancash:-Pallasca, Conchucos, Quebrada Chalhuacocha, Laguna Labrascocha [13] -8 15' 20.66" S, -77 44' 40.81" W (MUSM 23232); La Libertad: Santiago de Chuco, Quiruvilca, Campamento Callacuyán, Laguna Misha [5] -7 57' 32.87" S, -78 15' 8.17" W (MUSM 17429, 17430); Santiago de Chuco, Quiruvilca, Campamento Callacuyán, Laguna Negra [3] -7 56' 20.47" S, -78 14' 31.74" W (MUSM 17431 -Holotype); Santiago de Chuco, Quiruvilca, Laguna del Toro (MUSM 17247, 17248); Santiago de Chuco, Quiruvilca, Campamento Callacuyán, Quebrada Alto La Flor [10] -7 59' 45.20" S, -78 11' 27.31" W (MUSM 17432); Santiago de Chuco, Quiruvilca, Campamento Callacuyán -7 56' 20.47" S, -78 $14^{\prime} 31.74^{\prime \prime}$ W (MUSM 17436, 17437, 17438); Santiago de Chuco, Quiruvilca, arriba de Laguna Negra $-7^{\circ} 57^{\prime}$ 4.536" S, -78 14' 14.67" W (MUSM 17339); Santiago de Chuco, Quiruvilca, Lagunas Norte, Callacuyán -7 57' 40.61" S, -78 15' 35.32" W (MUSM 24755*, 24756*, 24757, 24758*, 24905, 24906*, 24907, 24908); Santiago de Chuco, Quiruvilca, Lagunas Norte, Shulcahuanga -7 56' 29.90" S, -78 15' 8.38" W (MUSM 24759, 24760*); Santiago de Chuco, Quiruvilca, Lagunas Norte, depresión camino a laguna Las Vizcachas $-7^{\circ}$ 55' 16.43" S, -78 14' 58.38" W (MUSM 24762*); Santiago de Chuco, Quiruvilca, Las Vizcachas -70 54' 54.47" S, -78 14' 59.14" W (MUSM 24763*, 24764*); Santiago de Chuco, Quiruvilca, Lagunas Norte, quebrada Pampa Huacha -7 58' 30. 72" S, -78 $16^{\prime}$ 46.236" W (MUSM 24765*); Santiago de Chuco, Quiruvilca, Lagunas Norte, quebrada San Francisco [11] -8 0' 0.83" S, -78 16' 59.56" W (MUSM 24767*, 24768*, 24769*, 24770, 24914*, 24915, 24916*); Santiago de Chuco, Quiruvilca, Lagunas Norte, Río Negro -7 55' 10.38' S, -78 15' 16.13" W (MUSM 24771, 24772*, 24773); Santiago de Chuco, Quiruvilca, Cruce entre el Río Grande y el Río Moche [8] -7 59' 8.45" S, 7-8 21' 13.21" W (MUSM 24903*, 24904); Santiago de Chuco, Quiruvilca, Lagunas Norte, quebrada Alto La Flor [7] -7 58' 33.89" S, -78 12' 29.81" W (MUSM 24909*); Santiago de Chuco, Quiruvilca, Lagunas Norte, quebrada Pampa Huacha [6] -7 58' 29.21" S, -78 16' 45.41" W (MUSM 24910*, 24911*, 24912*, 24913*); Santiago de Chuco, Quiruvilca, Lagunas Norte, quebrada Vira Vira [4] -7 57' 32.87" S, -78 $15^{\prime} 8.17^{\prime \prime} \mathrm{W}$ (MUSM 24917); Santiago de Chuco, Quiruvilca, Lagunas Norte, Río Caballo Moro [9] -7 59' 31.06" S, -78 14' 48.16" W (MUSM 24918*); Santiago de Chuco, Quiruvilca,

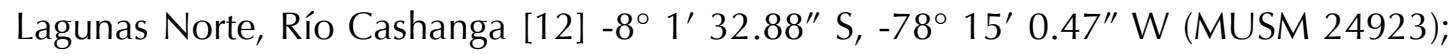
Santiago de Chuco, Quiruvilca, Lagunas Norte, Río Negro [2] -7 54' 59.87" S, -78 15' 20.63" W (MUSM 24924*, 24925, 24926); Cajamarca: Encañada, Combayo [1] -6 57' 39.492" S, -78² 27' 39.78" W (MUSM 26517, 26518, 26519, 26520). 
